\title{
A Study of a Baseboard
}

\section{Convector Heating System \\ in a Test Bungalow}

\author{
United States Department of Commerce \\ National Bureau of Standards \\ Building Materials and Structures Report BMS115
}




\section{BUILDING MATERIALS AND STRUCTURES REPORTS}

On request, the Superintendent of Documents, U. S. Government Printing Office, Washington 25 , D. C., will place your name on a special mailing list to receive notices of new reports in this series as soon as they are issued. There will be no charge for receiving such notices.

An alternative method is to deposit with the Superintendent of Documents the sum of $\$ 5$, with the request that the reports be sent to you as soon as issued, and that the cost thereof be charged against your deposit. This will provide for the mailing of the publications without delay. You will be notified when the amount of your deposit has become exhausted.

If 100 copies or more of any report are ordered at one time, a discount of 25 percent is allowed. Send all orders and remittances to the Superintendent of Documents, U.S. Government Printing Office, Washington $25, D$. C.

The following publications in this series are available by purchase from the Superintendent of Documents at the prices indicated:

BMS1

BMS2

BMS3

BMS4

BMS5

BMS6

BMS7

BMS8

BMS9

BMS10

BMS11

BMS12

BMS13

BMS14

BMS15

BMS16

BMS17

Suppleme

Supplement

BMS18

BMS19

BMS20

BMS21

BMS22

BMS23

BMS24

BMS25

BMS26

BMS27

BMS28

BMS29

BMS30

BMS31

"Out of print.
Research on Building Materials and Structures for Use in Low-Cost Housing............ * * Methods of Determining the Structural Properties of Low-Cost House Constructions. . . . . . 10

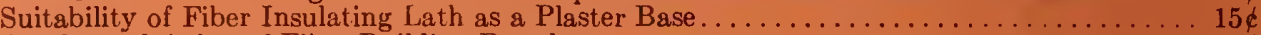

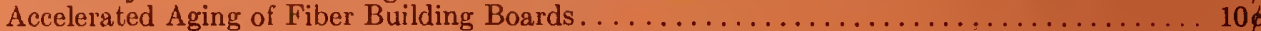

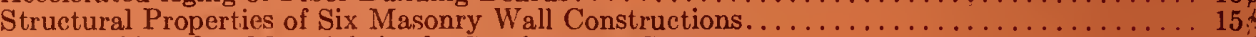

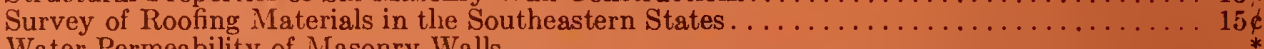

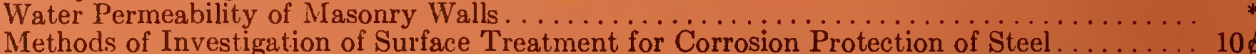

Methods of Investigation of Surface Treatment for Corrosion Protection of Steel ........... structions for Walls, Partitions, Floors, and Roofs ....................

Structural Properties of One of the "Keystone Beam Steel Floor" Constructions Sponsored by the H. H. Robertson Co. . .

Structural Properties of the Curren Fabrihome Corporation's "Fabrihome" Constructions for Walls and Partitions. .

Structural Properties of "Steelox" Constructions for Walls, Partitions, Floors, and Roofs

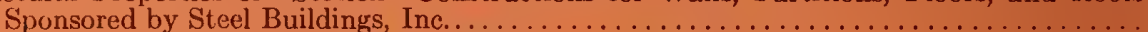

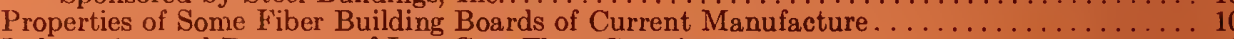

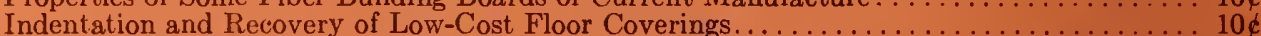

Structural Properties of "Wheeling Long-Span Steel Floor" Construction Sponsored by the

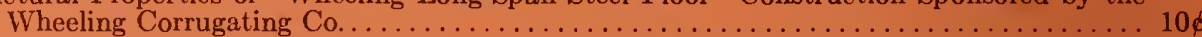

Structural Properties of a "Tilecrete" Floor Construction Sponsored by Tilecrete Floors, Inc. 10

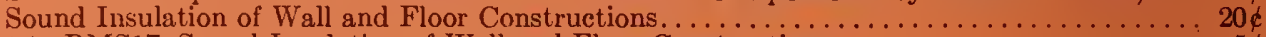

to BMS17, Sound Insulation of Wall and Floor Constructions $\ldots \ldots \ldots \ldots \ldots \ldots \ldots \ldots \ldots \ldots \ldots \ldots$

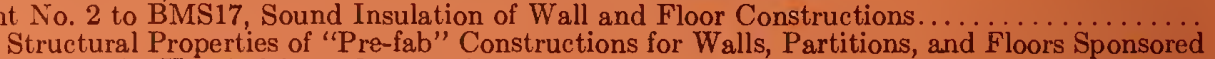



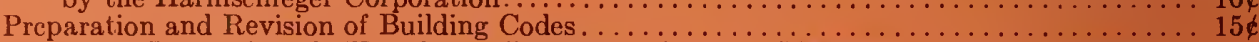

Structural Properties of "Twachtman" Constructions for Walls and Floors Sponsored by Connecticut Pre-Cast Buildings Corporation......................................... National Concrete Masonry Association...

Structural Properties of "Dun-Ti-Stone" Wall Construction Sponsored by the W. E. Dunn Manufacturing Co.

Structural Properties of a Brick Cavity-Wall Construction Sponsored by the Brick Manufacturers Association of New York, Inc.

Structural Properties of a Rcinforced-Brick Wall Construction and a Brick-Tile Cavity-Wall Construction Sponsored by the Structural Clay Products Institute...............

Structural I'roperties of Conventional Wood-Frame Constructions for Walls, Partitions,

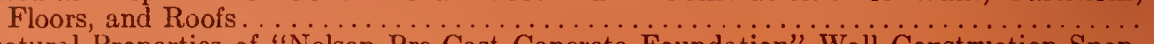

Structural Properties of "Nclson Prc-Cast Concrete Foundation" Wall Construction Sponsoled by the Nelson Cement Stonc Co., Inc........................................... Body Co.

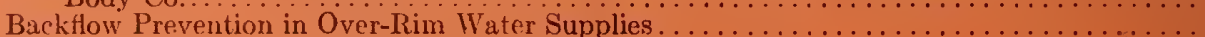

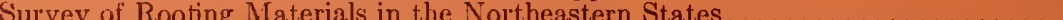

Structural Properties of a Wood-Frame Wall Construction Sponsored by the Douglas Fir

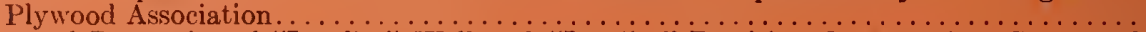

Structural Properties of "Insulite" Wall and "Insulite" Partition Constructions Sponsored

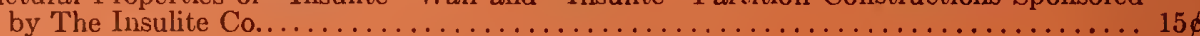

[List continued on cover page III] 


\section{A Study of a Baseboard}

\section{Convector Heating System}

\section{in a Test Bungalow}

by Paul R. Achenbach and Edward M. Tierney



Building Materials and Structures Report BMS115

Issued August 1, 1949

For sale by the Superintendent of Documents, U. S. Government Printing Office, Washington 25, D. C. Price 15 cents 


\section{Foreword}

The increase in construction of small houses without basements has resulted in efforts to provide heating systems that will produce comfort in such houses when the heater is located on the first floor. A recently developed distribution system that uses finned piping adjacent to all the exterior walls of a house at the baseboard level appears to offer greater comfort near the floor of basementless houses than some other systems now in use.

The tests described in this report were made to determine the temperatures produced at several levels above the floor with one form of baseboard heating system and to study the characteristics of two types of room-temperature controls with that kind of heating system in a partially insulated frame house. The project was part of the research program carried on at the National Bureau of Standards in cooperation with the Housing and Home Finance Agency and its technical staff.

E. U. Condon, Director.

II 


\title{
A Study of a Baseboard Convector Heating System in a Test Bungalow
}

\author{
by Paul R. Achenbach and. Edward M. Tierney
}

\begin{abstract}
The temperature distribution produced by a baseboard convector heating system was observed in a 4-room Test Bungalow on the grounds of the National Bureau of Standards. The distribution system consisted of finned sections of iron pipe placed beneath the windows, standard iron pipe connecting the finned elements in a continuous loop around the house at the baseboard level, and a hot-water boiler located on the first floor. The vertical temperature differences, roomto-room temperature differences, heat loss of the house, and the heat emission per unit length of finned pipe were observed for a range of outside air temperatures. In addition, the control of room temperature provided by an electric room thermostat and by an outdoor-thermostat control and modulating water-flow valve were compared for steady outside air temperatures. The characteristics of the outdoor-thermostat control and modulating water-flow valve were also studied for transient outside air temperatures and under pick-up conditions indoors.
\end{abstract}

\section{CONTENTS}

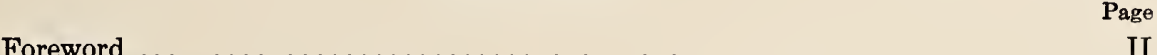



II. Test Equipment. . $\ldots \ldots \ldots \ldots \ldots \ldots \ldots \ldots \ldots \ldots \ldots \ldots \ldots \ldots \ldots \ldots \ldots \ldots \ldots, 3$

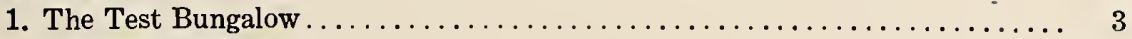

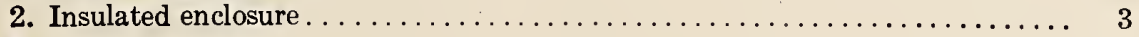



4. Controls . . . . . . . . . . . .

5. Temperature measurements $\ldots \ldots \ldots \ldots \ldots \ldots \ldots \ldots \ldots \ldots \ldots \ldots \ldots \ldots$

III. Test procedure $\ldots \ldots \ldots \ldots \ldots \ldots \ldots \ldots \ldots \ldots \ldots \ldots \ldots \ldots \ldots \ldots \ldots \ldots \ldots \ldots \ldots$

IV. Temperature distribution. $\ldots \ldots \ldots \ldots \ldots \ldots \ldots \ldots \ldots \ldots \ldots \ldots \ldots \ldots \ldots \ldots \ldots \ldots .8$



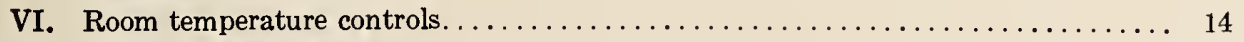

VII. Pick-up characteristics $\ldots \ldots \ldots \ldots \ldots \ldots \ldots \ldots \ldots \ldots \ldots \ldots \ldots \ldots \ldots \ldots \ldots \ldots \ldots 16$

VIII. Heat emission of convector $\ldots \ldots \ldots \ldots \ldots \ldots \ldots \ldots \ldots \ldots \ldots \ldots \ldots \ldots \ldots \ldots \ldots \ldots$

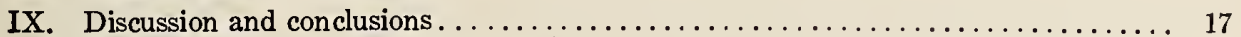

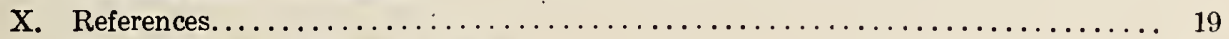

XI. Glossary of selected heating terms $\ldots \ldots \ldots \ldots \ldots \ldots \ldots \ldots \ldots \ldots \ldots \ldots \ldots \ldots \ldots \ldots 19$

\section{Introduction}

The various combinations of dry-bulb temperature, relative humidity, and air motion necessary to provide comfort in homes in the United States using convection heating have been established by the American Society of Heating and Ventilating Engineers and are illustrated in comfort charts prepared by that Society. Lower room temperatures are considered comfortable in some European countries; for example, the living-room temperature in British houses is seldom much above $60^{\circ} \mathrm{F}$ and bedroom temperatures are often in the range from $50^{\circ}$ to $55^{\circ} \mathrm{F}$ [1]. ${ }^{1}$ In actual practice; however, in America many heating systems provide means for regulation of the dry-bulb temperatures only. The relative humidity and air circulation in the living space are partially controlled by these heating systems.

\footnotetext{
1 Figures in brackets indicate the literature references at the end of this paper.
}

The temperature differences in the region from the floor to head level and from room to room are of primary importance in heated houses. The objective in American houses is to heat all rooms uniformly and to have a minimum temperature gradient in a vertical direction. Uniformity of temperature is difficult, if not impossible, to attain, especially with inexpensive heating devices or systems. In houses with basements the heat liberated by a boiler, furnace, or piping in the basement assists greatly in warming the floor above [2]. However, in recent years, a great many small houses have been built with concrete floors laid on the ground or with floors laid over shallow crawl spaces. In such constructions, the lack of basement spaces necessitates placing the heating plant on the first floor, which in most cases prevents direct warming of the under side of the floor. 
A great many different heat-distribution systems have been tried in houses in an attempt to produce a uniform temperature in all rooms and at all levels. Warm air, hot water, and steam have been employed as media for conveying heat in various installations, and it has been found that the results with each depend in part upon the size, shape, and location of the heating elements and in part upon the physical characteristics of the medium used. Experiments at the University of Illinois [3] have shown that long, low, thin, direct radiators produce smaller floor-to-ceiling temperature differentials than high radiators, which indicates that better temperature distribution may be provided in a room when the heat is supplied by laterally distributed heating surfaces near the floor than by tall units concentrated over a small floor area. Further development guided by this principle has led to the manufacture of radiant baseboard elements and baseboard convectors.

Several types of baseboard heating systems have been developed recently. Hollow cast-iron elements, either with or without fins [4], have been used in some types and finned steel pipe or finned copper tubing with shields or covers partially enclosing the heating elemerts in others. Such systems provide heating surfaces near the floor by using elements around the entire perimeter of the living space which are not much thicker or higher than a baseboard. These heating elements are sometimes referred to as floor-line radiation or baseboard radiation. In addition to the advantage of low vertical temperature differentials, this type of system occupies practically no usable living space.
A disadvantage of the baseboard heating system, however, arises from the use of a distribution system consisting of a continuous loop of pipe around the inside of the house. With this arrangement, the heat cannot be shut off in one room without shutting it off in all rooms; thus resulting in a waste of heat in bedrooms in which windows are opened at night for ventilation. Of course, this undesirable feature can be remedied by using two parallel piping. circuits with one to heat the bedrooms and the other to heat the remainder of the house.

The continuous piping circuit also necessitates more accurate design of the individual elements for the several rooms of a house since it permits no simple method for decreasing or increasing the heat output of a particular convector with relation to the others if that particular convector has too much or too little heating surface. The conventional hotwater heating system with free-standing radiators can be "balanced" by partially closing the valve on a radiator that has too much heating surface.

One type of baseboard heating system was installed in the Test Bungalow at the National Bureau of Standards to study the temperature distribution produced in a typical four-room house and to investigate the installation and operational problems involved in its use. A photograph of the Test Bungalow is shown in figure 1.

The above-mentioned system had iron pipe with fins under the windows and pipe without fins around the walls, partially enclosed by a perforated sheet-metal cover. Heat was transferred primarily by convection of air through the enclosure and over

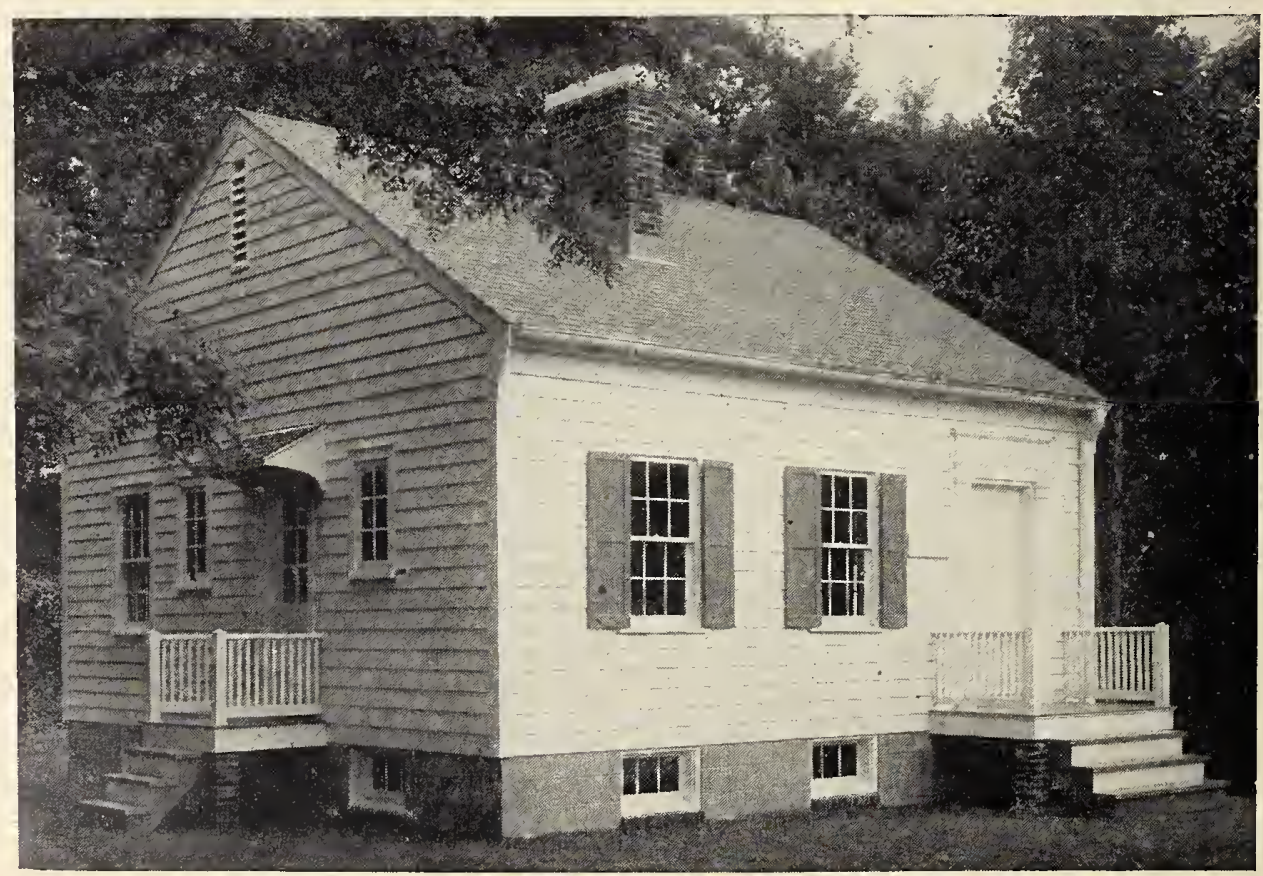

Figure 1. Test Bungalow before insulated enclosure was built. 
the pipe and fin surface; hence, the systcm has been termed a baseboard convector heating system in this discussion.

Two types of controls were used for the tests; a conventional wall-type electric room thermostat and a modulating control system with an outdoorthermostat control and a threc-way mixing valve that blended the boiler supply and return water to control the temperature of the water entering the system.

\section{Test Equipment}

\section{The Test Bungalow}

The Test Bungalow at the National Bureau of Standards is of conventional frame construction and has four rooms and bath, connected by a hallway located approximately in the center of the house. There is a full basement under the entire house although this feature was not a consideration in the tests discussed herein. A floor plan of the Test Bungalow is shown in figure 2.

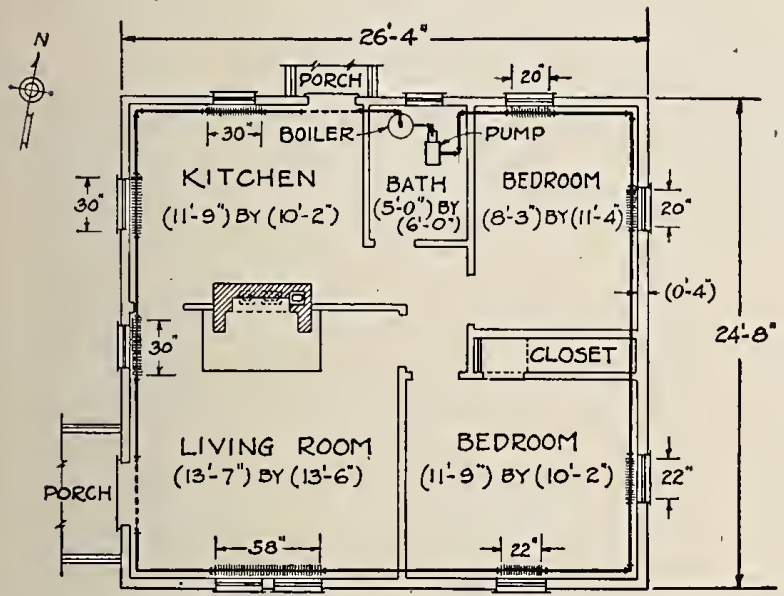

Figure 2. Floor plan of Test Bungalow showing the piping circuit and the location and size of the baseboard convector elements.

The outside walls, which are without insulation, consist of 2 - by 4 -in. studding with sheathing and lap siding separated by a layer of building paper on the outside and 1/2-in. plasterboard nailed directly to the studding on the inside. The floor consists of pine subflooring and 13/16-in. tongue-and-grooved pine finish flooring laid on 2 - by 10 -in. joists with building paper between. The basement ceiling is 1-in. rigid insulation board nailed directly to the underside of the floor joists. The ceiling of the living quarters is $1 / 4$-in. plywood supported by a framework of 2 - by 4 -in. members and the ceiling height in all rooms except the bathroom can be adjusted by means of screw jacks permanently mounted in the construction. Ceilings are insulated from the unfinished attic space by $3 \frac{5}{8}$-in. rock wool batts. All windows in the living quarters are double-hung except one casement window in the kitchen and one in the bathroom. The basement occupies the entire space below the living quarters. The foundation walls are of concrete block and the floor is concrete.

For the current tests, the ceiling height was $8 \mathrm{ft}$. Insulation was installed over the ceiling and under the floor joists and the windows and doors were weather-stripped in order to reduce the heat loss of the Test Bungalow to approximately $55 \mathrm{Btu} / \mathrm{hr}$ $\left(\mathrm{ft}^{2}\right)$ of interior floor area for an inside-outside air temperature difference of $70 \mathrm{deg} \mathrm{F}$. This heat loss value $^{2}$ is being used in some parts of the Unitcd States at the present time as a guide for determining the amount of insulation to be used in new construction. The computed heat losses for the several rooms of the Test Bungalow, assuming an infiltration of one air change per hour, are summarized in table 1 .

TABLE 1. Computed heat loss of the Test Bungalow for an inside-outside air temperature difference of $70^{\circ} \mathrm{F}$

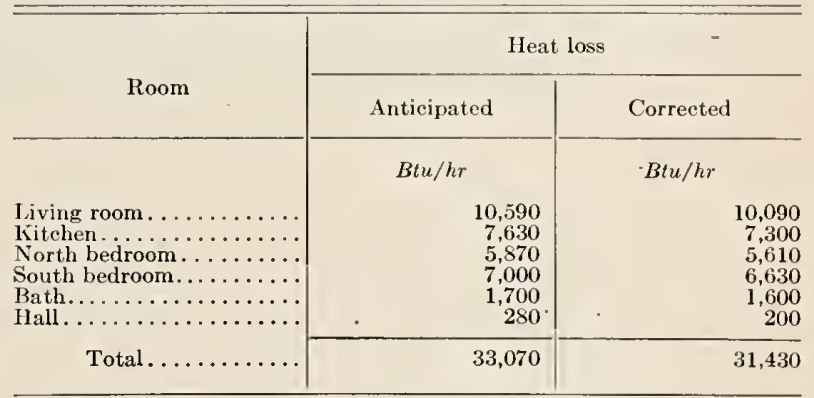

The heat losses, based upon the tempcratures anticipated in the basement and attic, were computed for each room before the tests were made. After the tests were completed, the heat losses were computed again using the observed temperatures in the basement and attic. Table 1 shows that the anticipated heat loss was $33,070 \mathrm{Btu} / \mathrm{hr}$ (equivalent to $53.7 \mathrm{Btu} / \mathrm{hr}\left(\mathrm{ft}^{2}\right)$ of floor area) for an insideoutside air temperature difference of $70 \mathrm{deg} F$, whereas the second computation shows that the heat loss would be only $31,430 \mathrm{Btu} / \mathrm{hr}$ (equivalent to $51.0 \mathrm{Btu} / \mathrm{hr}\left(\mathrm{ft}^{2}\right)$ of floor area).

\section{Insulated Enclosure}

Completely surrounding the Test Bungalow, and at a distance of approximately $5 \mathrm{ft}$ from its outside walls, is a heavily insulated enclosure without windows. A large unit cooler, installed in the space between the bungalow and the enclosure, makes it possible to maintain the air around the bungalow at selected temperatures down to approximately $0^{\circ}$ F. Air is circulated around the bungalow at a rate of about $9,000 \mathrm{cfm}$, but the maximum air velocity adjacent to the exterior wall is approximately 2

\footnotetext{
2 The various local offices of the Federal Housing Administration are accepting construction with heat losses ranging from 50 to $70 \mathrm{Bt} / \mathrm{l} / \mathrm{hr}\left(\mathrm{ft}^{2}\right)$ of floor area at the design inside-outside air temperature difference for different sections of the country.
} 




Figure 3. Insulated enclosure for the Test Bungalow.

mph. The outside air temperatures at the four corners of the bungalow do not differ more than 2 $\operatorname{deg} \mathrm{F}$ at the lowest temperature obtainable. The refrigerating system and enclosure thus provide a means for studying heating systems under controlled conditions, regardless of outdoor weather conditions or temperature. A photograph of the insulated enclosure is shown in figure 3 .

\section{Heating System}

The heat-distribution system selected for test consisted of lengths of finned 11/4-in. black iron pipe under each window and 1-in. standard pipe to

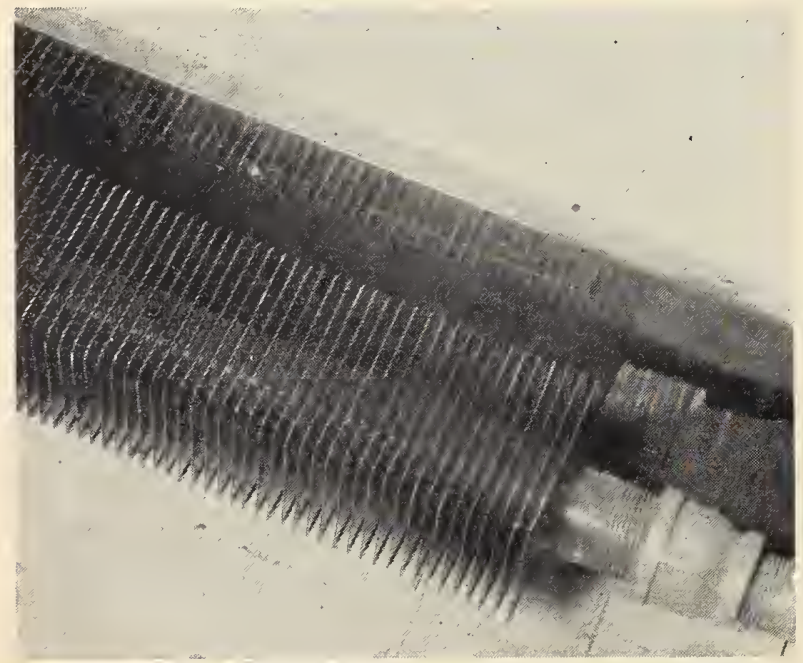

Figure 4. Close-up view of a finned convector element without the sheet-metal enclosure. form a continuous circuit around the perimeter of the house as shown on the floor plan of the Test Bungalow in figure 2. After the hot water had left the boiler it was pumped through the rooms in the following order: kitchen, living room, south bedroom, and north bedroom. A close-up view of one of the finned elements is shown in figure 4 , and the method of installing the connecting pipe is shown in figure 5 . The lengths of the finned sections in each room (shown on the floor plan in fig. 2) were chosen so that their computed heat outputs were equal to the computed heat loss of that room. The fins were $31 / 2$-in. square and were spaced $1 / 4$-in. apart on the pipe. A perforated metal enclosure partially covered the convector elements and piping as illustrated in figure 6. A cross-sectional drawing of the finned pipe, its supports, and the metal cover is shown in figure 7 . This drawing also shows the method of installation of the convectors and their location relative to the floor and outside wall surfaces. The lower $10 \mathrm{in}$. of the plasterboard was removed from the wall and a nailing strip $3 / 4$ by $13 / 4$ in. was nailed to the studding at the bottom of the remaining plasterboard. The pressed-steel panel forming the back of the convector housing was then secured to the nailing strip and floor. Metal support brackets were screwed to the studding at intervals to support the convectors and piping. After placing the heating elements on the brackets and assembling the connecting piping, the metal cover was screwed to the nailing strip and the studding. The metal cover for the system used in the tests extended $31 / 2$ in. out into the room from the wall surface and the skirt of the cover had a clearance of 2 in. above 


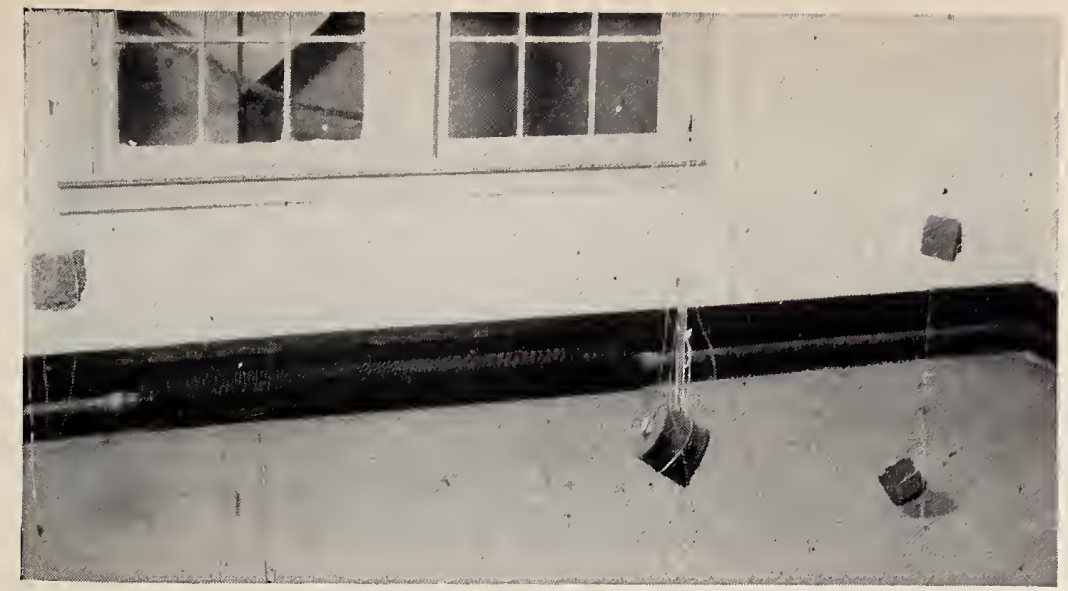

Figure 5. Baseboard convector without the sheet-metal enclosure showing the method of installing the connecting pipes.



Figure 6. Baseboard convector in the living room with the perforated metal housing in place. The warm air register near the door has no connection with the baseboard convector system.

the floor surface to permit air circulation over the heating elements.

Where the pipe would otherwise have obstructed an outside doorway, it passed in a downward loop through the floor and insulation, thence under the insulation for a distance a little greater than the width of the door opening, and back up through the floor and insulation on the other side of the doorway. An air valve was attached to each of these loops adjacent to the door to permit removal of air that might accumulate at these places. The treatment of the piping at the exterior doors can be observed in figure 6 .

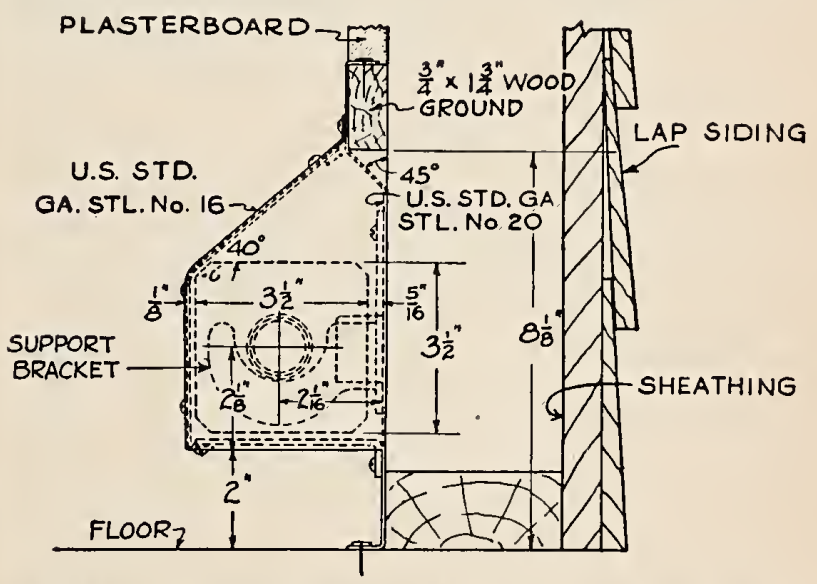

Figure 7. Vertical cross section of the baseboard convector showing the method of installation and the location of the elements relative to the wall and floor.

An experimental electric boiler was used to supply hot water to the sustem. It consisted of a cylindrical shell 6 in. in diameter containing seren hairpin-type immersion electric heaters with a total capacity of $14 \mathrm{kw}$. Electric energy was supplied to these heaters through calibrated watthour meters so that the heat input of the system could be accurately determined. A centrifugal pump was used to circulate the water through the boiler and the heating system. The electric energy used by the 1/4-hp motor on the pump was also measured. The pump was located in the piping circuit near the inlet of the boiler. It circulated approximately $10 \mathrm{gal} / \mathrm{min}$ of water through the heating circuit. At this rate of flow the drop in water temperature around the circuit was $2.2 \mathrm{deg} \mathbf{F}$ for an outside air temperature of $50^{\circ} \mathrm{F}$, and increased to $5.1 \mathrm{deg} \mathrm{F}$ for an outside 


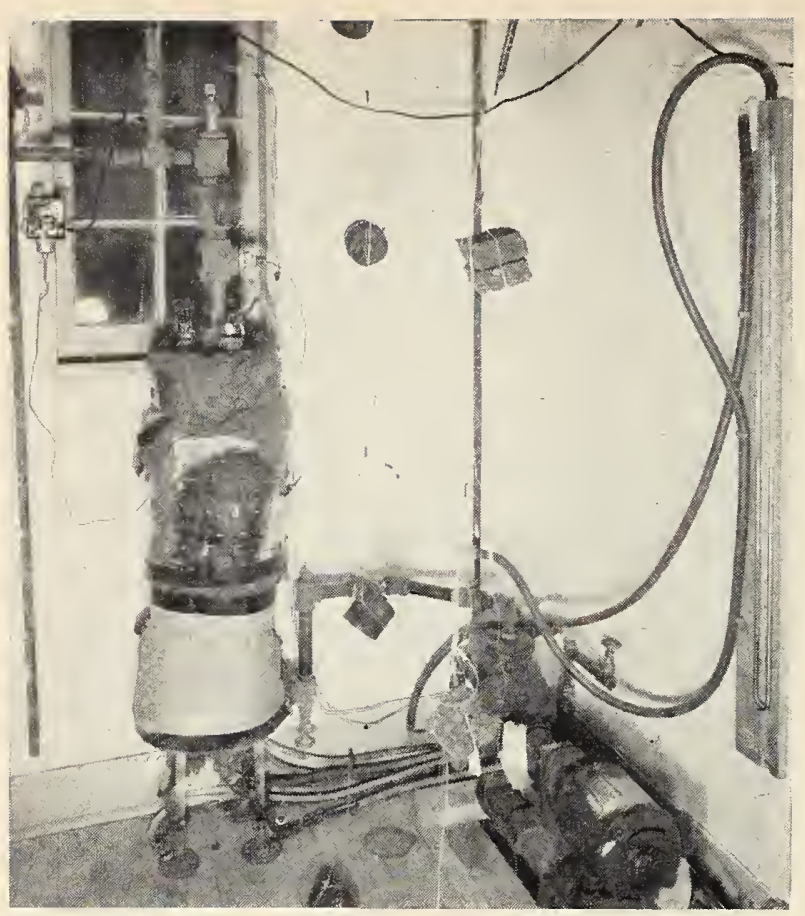

Figure 8. Experimental hot-water boiler, circulating pump, controls, and adjacent piping for the tests with an electric room thermostat.

air temperature of $1^{\circ} \mathrm{F}$. Figure 8 shows the experimental boiler, circulating pump, expansion tank, controls, and adjacent piping. The manometer, shown at the right on figure 8 , was used to indicate the pressure difference between the suction and discharge connections of the pump.

The boiler and circulating pump were located in the space that would normally be the bathroom in the Test Bungalow to simulate a first-floor installation in a basementless house. The heating system was a closed system with the expansion tank placed just below the ceiling.

\section{Controls}

Two types of heating-system controls were used during these investigations. The first consisted of a commercial low-voltage electric room thermostat, a relay, an immersion aquastat, and a temperaturelimit control. The thermostat and relay connected and disconnected the electric heaters from the power supply, and the immersion aquastat operated the circulating pump intermittently in response to changes of the water temperature at the boiler outlet. The temperature-limit control interrupted the electric-heater circuit when the boiler supply water reached the maximum desired temperature. A wiring diagram of the first type of heating system controls is shown in figure 9. The locations of the acquastat and temperature-limit control for this system are shown in figure 8 . The thermostat had a spiral bimetallic element approximately 14 in. long with a small magnet secured to the free end. This magnet closed the circuit in a drop of mercury by attracting a small piece of iron attached to the contact arm. The thermostat was mounted 30 in. above the floor on the east wall of the living room adjacent to the archway connecting the living room and the hall.

The second heating-system control consisted of an outdoor thermostat, a motorized three-way valve, an immersion aquastat, and an electric control circuit for adjusting the three-way mixing valve position. This system blended the boiler supply water and the cooler water returning from the heating system in various proportions by means of a bypass line as determined by the temperatures of the outside thermostat bulb and the bulb immersed in the mixed water. When rapid changes of

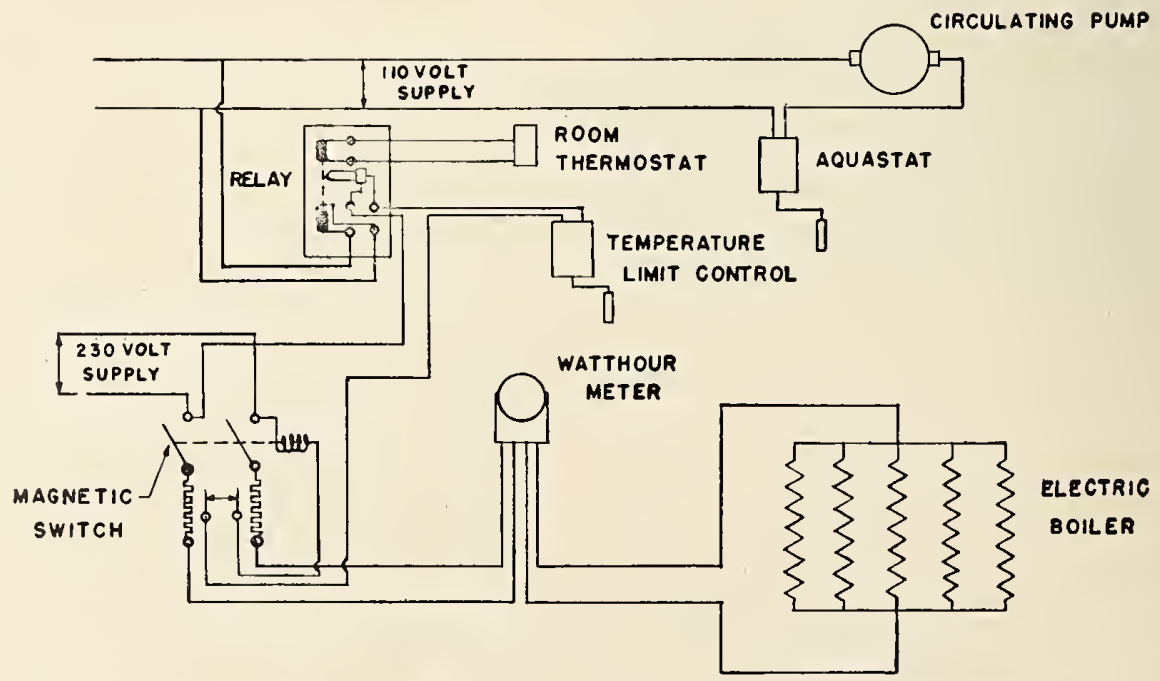

Figure 9. Diagram of the electric circuits for the tests with the electric room-thermostat control system. 


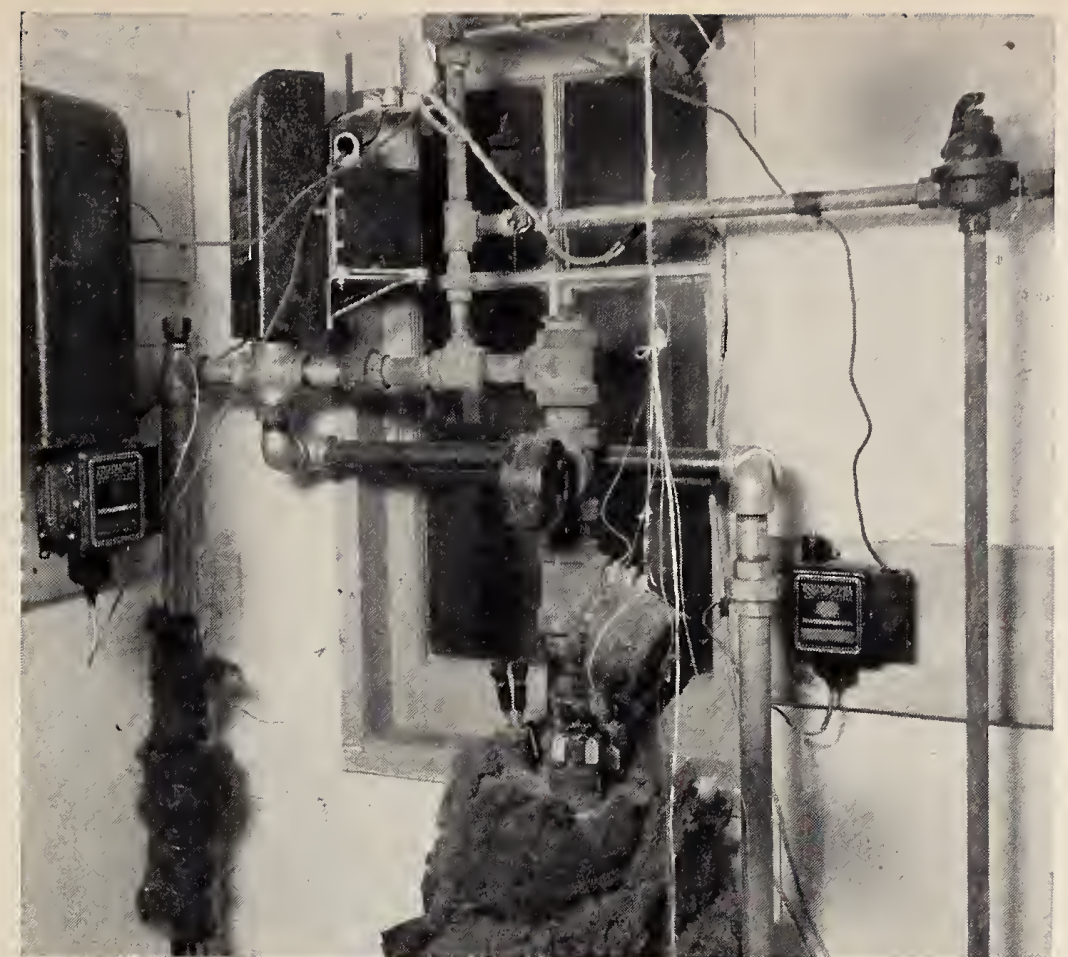

FIGURE 10. Experimental hot-water boiler and attached piping showing the three-way mixing valve and some of the other controls used with the outdoor-thermostat control system.

the mixed-water temperature were required, the three-ivay valve could fully close either the bypass line to raise the temperature or the boiler supply line to lower the temperature of the water supplied to the distribution system. The control system was designed to modulate the temperature of the water entering the distribution system in just the proper way to make the heat output of the system equal the heat loss of the house for any outside air temperature. Most of the control equipment for this system is visible in figure 10. A diagrammatic sketch of the wiring circuits and the piping arrangement for the modulating control system is shown in figure 11 .

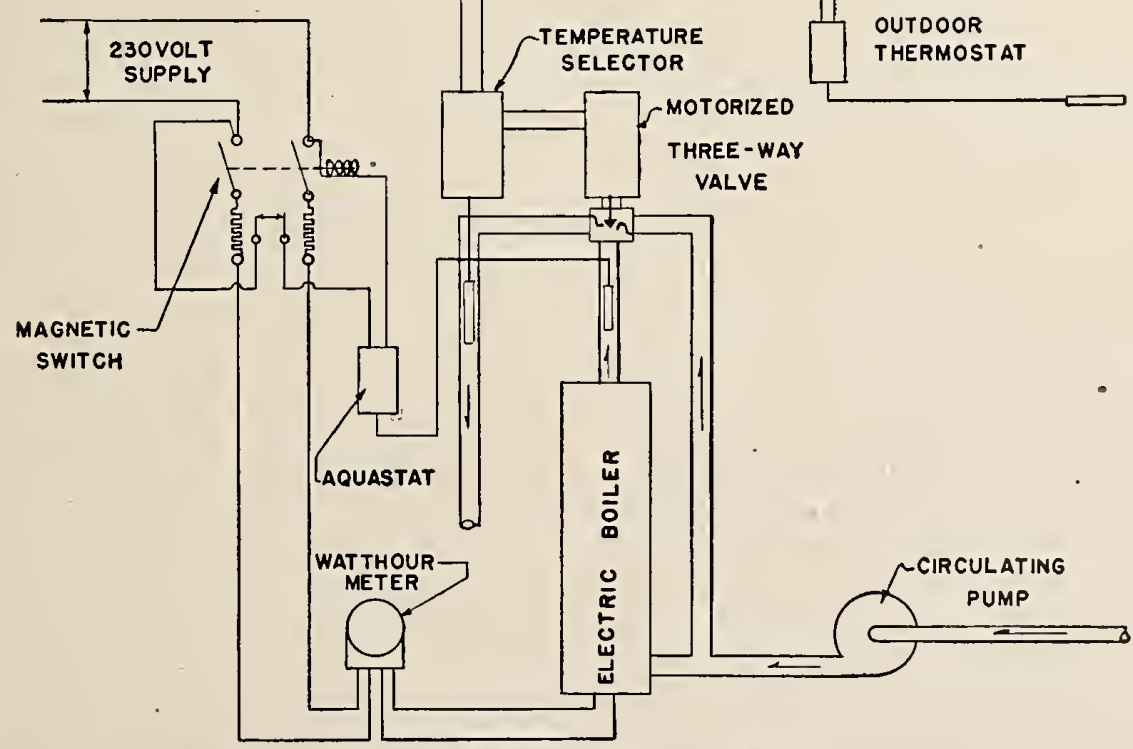

Figure 11. Diagram of the electric and piping circuits for the modulating-temperature control system. 


\section{Temperature Measurements}

Temperatures were measured in the Test Bungalow by means of thermocouples supported by strings attached to the ceiling. Five strings carrying five thermocouples each, were located in the kitchen, living room, and the two bedrooms, with one string suspended at the center of each room and one midway between the center and each corner of these rooms. Three strings of five thermocouples each, were suspended in the bathroom. The five thermocouples on each string were permanently installed at distances of $2,30,60,78$, and 94 in. above the floor. To eliminate the fluctuations of temperature caused by the cycling of the thermostat and any minor changes due to opening the outside doors, these thermocouples were attached to blocks of copper $3 / 4$ in. in diameter and $3 / 4$ in. long and were enclosed in blocks of cork. Thus, the temperatures observed in all rooms could be compared, even though approximately $45 \mathrm{~min}$ were required to take all the observations. The effect on the temperatures of covering the thermocouples with cork insulation is described in an earlier Building Materials and Structures Report [5].

Other thermocouples were used to measure the temperatures outside of the bungalow, on the inside and outside surfaces of the exterior walls, on the floor surfaces, in the basement, in the attic, and at several places on the hot-water pipes of the convector heating system encircling the inside walls of the house.

\section{Test Procedure}

The temperature distribution was observed in the Test Bungalow with an inside temperature of $70^{\circ} \mathrm{F}$ maintained at the 30-in. level in the living room and outside air temperatures of $50^{\circ}, 32^{\circ}, 20^{\circ}$, and as near $0^{\circ} \mathrm{F}$ as could be attained. With the room thermostat controlling the boiler, a series of tests was made for this range of outside air temperatures with the interior doors closed to determine whether or not the heat output of the convector elements equaled the heat loss on a room-by-room basis. The series was then repeated with the interior doors open. When the modulating control with the outdoor thermostat was used, temperature distributions were observed for a range of outside air temperatures from $1^{\circ}$ to $50^{\circ} \mathrm{F}$ with the interior doors closed.

Before starting the tests for each set of conditions, the temperatures inside and outside the bungalow were maintained constant for enough time to permit the temperatures in the attic and basement to reach a steady state. During the test period, which was usually of 24 hours duration, hourly observations were made of the outside air temperature, the temperature at the 30 -in. level in the living room, the basement temperature, the attic temperature, and the electric-energy consumption. At 4-hour intervals, temperatures were observed at all stations on the inside and outside of the bungalow.

In addition to the investigation of the temperature distribution in the four rooms of the Test Bungalow with a constant outside air temperature, the characteristics of the modulating-valve and outdoor-thermostat control system were observed when the outside air temperature was varied between $0^{\circ} \mathrm{F}$ and $40^{\circ} \mathrm{F}$ and back as rapidly as the refrigerating system permitted.

The pick-up characteristics of the baseboardconvector system, when controlled by the outdoorthermostat control, were also observed. The two bedrooms were cooled down to $50^{\circ} \mathrm{F}$ by opening the windows to simulate the practice of ventilating sleeping rooms. When the temperature in the bedrooms reached $50^{\circ} \mathrm{F}$, the windows were closed and the rise in temperature was observed with the interior doors closed. The temperatures in the kitchen and living room and the supply-water temperature were also recorded during this transient condition.

\section{Temperature Distribution}

The averages of the temperatures observed at each of five levels above the floor in the several rooms of the Test Bungalow are tabulated in tables 2 to 9 , inclusive, for the tests using the roomthermostat control and in tables 10 to 13 , inclusive, for the tests using the outdoor-thermostat control. The maximum horizontal temperature difference between any two rooms of the house and the vertical temperature differences between levels are also shown in these tables.

An examination of tables 2 to 13 shows that comparatively small temperature differences existed between rooms and between different levels in the same room with the baseboard convector heating system for the range of outside air temperatures from $50^{\circ}$ to $0^{\circ} \mathrm{F}$. The temperature differences increased in magnitude both horizontally and vertically as the outside air temperature decreased. The vertical temperature gradient ranged from $0.3 \mathrm{deg}$ $\mathrm{F} / \mathrm{ft}$ above the floor for an outside air temperature of $50^{\circ} \mathrm{F}$ to $0.8 \mathrm{deg} \mathrm{F} / \mathrm{ft}$ for an outside air temperature of $0^{\circ} \mathrm{F}$. A comparison of the results obtained with the interior doors of the bungalow open (tables 2 to 5 , inclusive) with those with the doors closed (tables 6 to 9, inclusive) shows that the temperature differences in a vertical direction were not appreciably affected by closing the doors, but that the maximum temperature difference between rooms was approximately doubled for the levels 2,30 , and 60 in. above the floor by closing the doors. The 
maximum difference between the average temperatures in the living zone ${ }^{3}$ of any two rooms ranged from $0.7 \mathrm{deg}$ to $1.4 \mathrm{deg} \mathrm{F}$ with the interior doors open and from $1.4 \mathrm{deg}$ to $3.1 \mathrm{deg} F$ with the interior doors closed for an outside air temperature range from $50^{\circ}$ to $0^{\circ} \mathrm{F}$.

TABLE 2. Temperature distribution produced by baseboard convector with room thermostat (inside doors open)

Outside air temperature $49.9^{\circ} \mathrm{F}$. Heat input $8,650 \mathrm{Btu} / \mathrm{hr}$.

\begin{tabular}{|c|c|c|c|c|c|c|}
\hline \multirow{2}{*}{$\begin{array}{l}\text { Height } \\
\text { above } \\
\text { floor }\end{array}$} & \multicolumn{5}{|c|}{ A. Average room temperature } & \multirow{2}{*}{$\begin{array}{c}\text { Maximum } \\
\text { horizontal } \\
\text { temperature } \\
\text { difference } \\
\text { between } \\
\text { rooms }^{\mathrm{a}}\end{array}$} \\
\hline & $\begin{array}{l}\text { Living } \\
\text { room }\end{array}$ & Kitchen & $\begin{array}{l}\text { North } \\
\text { bed- } \\
\text { room }\end{array}$ & $\begin{array}{l}\text { South } \\
\text { bed- } \\
\text { room }\end{array}$ & Bath & \\
\hline \multirow[t]{2}{*}{$\begin{array}{l}\text { in. } \\
2 \ldots \ldots \ldots \\
30 \ldots \ldots \\
60 \ldots \ldots \\
78 \ldots \ldots \ldots \\
94 \ldots \ldots \ldots\end{array}$} & $\begin{array}{l}{ }^{\circ} \mathrm{F} \\
69.2 \\
70.2 \\
70.6 \\
70.6 \\
71.1\end{array}$ & $\begin{array}{l}{ }^{\circ} \mathrm{F} \\
69.4 \\
70.7 \\
71.0 \\
71.6 \\
72.0\end{array}$ & $\begin{array}{l}{ }^{\circ} \mathrm{F} \\
69.1 \\
69.8 \\
70.1 \\
70.6 \\
71.0\end{array}$ & $\begin{array}{l}{ }^{\circ} F \\
69.1 \\
70.1 \\
70.4 \\
70.8 \\
71.1\end{array}$ & $\begin{array}{l}{ }^{\circ} \mathrm{F} \\
72.7 \\
74.3 \\
75.5 \\
77.6 \\
78.0\end{array}$ & $\begin{array}{c}\text { Deg F } \\
0.3 \\
.9 \\
.9 \\
1.0 \\
1.0\end{array}$ \\
\hline & \multicolumn{5}{|c|}{ B. Vertical temperature difference } & $\begin{array}{l}\text { Average } \\
\text { for } \mathrm{B}^{\mathrm{a}}\end{array}$ \\
\hline $\begin{array}{l}2 \text { to } 60 \ldots \\
2 \text { to } 94 \ldots\end{array}$ & $\begin{array}{r}D e g F \\
1.4 \\
1.9\end{array}$ & $\begin{array}{r}D e g F \\
1.6 \\
2.6\end{array}$ & $\begin{array}{r}D \operatorname{leg} F \\
1.0 \\
1.9\end{array}$ & $\begin{array}{r}D e g F \\
1.3 \\
2.0\end{array}$ & $\begin{array}{r}\operatorname{Deg} F \\
2.8 \\
5.3\end{array}$ & $\begin{array}{c}D e g F \\
1.3 \\
2.1\end{array}$ \\
\hline
\end{tabular}

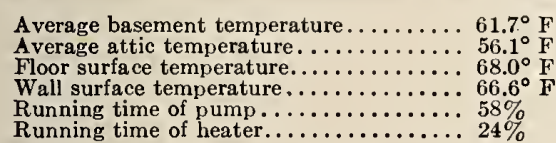

- Bathroom data not included.

TABLE 3. Temperature distribution produced by baseboard convector with room thermostat (inside doors open)

Outside air temperature $31.6^{\circ} \mathrm{F}$. Heat input $16,280 \mathrm{Btu} / \mathrm{hr}$.

\begin{tabular}{|c|c|c|c|c|c|c|}
\hline \multirow{2}{*}{$\begin{array}{l}\text { Height } \\
\text { above } \\
\text { floor }\end{array}$} & \multicolumn{5}{|c|}{ A. Average room temperature } & \multirow{2}{*}{$\begin{array}{c}\text { Maximum } \\
\text { horizontal } \\
\text { temperature } \\
\text { difference } \\
\text { between } \\
\text { rooms }^{\mathbf{B}}\end{array}$} \\
\hline & $\begin{array}{l}\text { Living } \\
\text { room }\end{array}$ & Kitchen & $\begin{array}{l}\text { North } \\
\text { bed- } \\
\text { room }\end{array}$ & $\begin{array}{l}\text { South } \\
\text { bed- } \\
\text { room }\end{array}$ & Bath & \\
\hline \multirow[t]{2}{*}{$\begin{array}{c}\text { in. } \\
2 \ldots \ldots \ldots \\
30 \ldots \ldots \ldots \\
60 \ldots \ldots \ldots \\
78 \ldots \ldots \ldots\end{array}$} & $\begin{array}{l}{ }^{\circ} F \\
68.2 \\
70.1 \\
70.4 \\
70.5 \\
71.6\end{array}$ & $\begin{array}{l}{ }^{\circ} \mathrm{F} \\
67.8 \\
70.2 \\
70.9 \\
71.9 \\
72.7\end{array}$ & $\begin{array}{l}\circ \mathrm{F} \\
67.9 \\
69.7 \\
69.9 \\
70.4 \\
71.0\end{array}$ & $\begin{array}{l}{ }^{\circ} F \\
68.6 \\
70.3 \\
70.9 \\
71.5 \\
71.8\end{array}$ & $\begin{array}{l}{ }^{\circ} \mathrm{F} \\
73.4 \\
76.0 \\
78.4 \\
80.8 \\
81.8\end{array}$ & $\begin{array}{c}D e g . F \\
0.8 \\
0.6 \\
1.0 \\
1.5 \\
1.7\end{array}$ \\
\hline & \multicolumn{5}{|c|}{ B. Vertical temperature difference } & $\begin{array}{l}\text { Average } \\
\text { for } B^{\mathrm{a}}\end{array}$ \\
\hline $\begin{array}{l}2 \text { to } 60 \ldots \\
2 \text { to } 94 \ldots .\end{array}$ & $\begin{array}{r}D e g F \\
2.2 \\
3.4\end{array}$ & $\begin{array}{r}D e g \\
3.1 \\
4.9\end{array}$ & $\begin{array}{r}D e g_{F} \\
2.0 \\
3.1\end{array}$ & $\begin{array}{r}D e g F \\
2.3 \\
3.2\end{array}$ & $\begin{array}{r}D e g F \\
5.0 \\
8.4\end{array}$ & $\begin{array}{c}D e g F \\
2.4 \\
3.7\end{array}$ \\
\hline
\end{tabular}

- Average basement temperature........ $55.2^{\circ} \mathrm{F}$

Average attic temperature $\ldots \ldots \ldots \ldots \ldots, 46.8^{\circ} \mathrm{F}$

Floor surface temperature................. $66.3^{\circ} \mathrm{F}$

Wall surface temperature ............... $64.1^{\circ}$

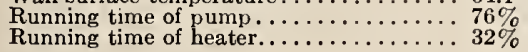

- Bathroom data not included.

3 The space between levels 2 in, and 60 in. above the floor is called the living zone in this report.
TABLe 4. Temperature distribution produced by baseloard convector with room thermostat (inside doors open)

Outside air temperaturc $20.7^{\circ} \mathrm{F}$. Hcat input $22,410 \mathrm{Btu} / \mathrm{hr}$

\begin{tabular}{|c|c|c|c|c|c|c|}
\hline \multirow{2}{*}{$\begin{array}{l}\text { Height } \\
\text { above } \\
\text { floor }\end{array}$} & \multicolumn{5}{|c|}{ A. Average room temperature } & \multirow{2}{*}{$\begin{array}{l}\text { Maximum } \\
\text { lorizontal } \\
\text { temperature } \\
\text { differenec } \\
\text { betweer } \\
\text { rooms }\end{array}$} \\
\hline & $\begin{array}{l}\text { Living } \\
\text { room }\end{array}$ & Kitchen & $\begin{array}{l}\text { North } \\
\text { bed- } \\
\text { room }\end{array}$ & $\begin{array}{l}\text { South } \\
\text { bed- } \\
\text { room }\end{array}$ & Bath & \\
\hline \multirow[t]{2}{*}{$\begin{array}{l}\text { in. } \\
2, \ldots \ldots \\
30 \ldots \ldots \\
60 \ldots \ldots \\
78 \ldots \ldots \\
94 \ldots \ldots\end{array}$} & $\begin{array}{l}{ }^{\circ} F \\
67.2 \\
69.8 \\
70.5 \\
70.7 \\
71.9\end{array}$ & \begin{tabular}{l|l}
${ }^{\circ} \mathrm{F}$ \\
66.5 \\
70.3 \\
71.2 \\
72.3 \\
73.1
\end{tabular} & $\begin{array}{l}{ }^{\circ} F \\
66.7 \\
69.1 \\
69.8 \\
70.3 \\
70.9\end{array}$ & $\begin{array}{l}{ }^{\circ} F \\
67.1 \\
69.5 \\
70.2 \\
70.8 \\
71.8\end{array}$ & \begin{tabular}{l|l} 
& \\
72.6 \\
77.2 \\
80.1 \\
82.3 \\
83.2
\end{tabular} & \multirow{2}{*}{$\begin{array}{c}\text { Deg F } \\
0.7 \\
1.2 \\
1.4 \\
2.0 \\
2.2 \\
\begin{array}{c}\text { Average } \\
\text { for } \mathrm{B}^{\mathrm{a}}\end{array}\end{array}$} \\
\hline & \multicolumn{5}{|c|}{ B. Vertical temperature difference } & \\
\hline \multirow[t]{2}{*}{$\begin{array}{l}2 \text { to } 60 \ldots \\
2 \text { to } 94 \ldots\end{array}$} & $\begin{array}{r}D e g F \\
3.3 \\
4.7\end{array}$ & $\begin{array}{r}D e g \\
4.7 \\
6.6\end{array}$ & $\begin{array}{r}D e g F \\
3.1 \\
4.2\end{array}$ & $\begin{array}{r}D e g F \\
3.1 \\
4.7\end{array}$ & $\begin{array}{r}D e g F \\
7.5 \\
10.6\end{array}$ & $\begin{array}{c}D e g F \\
3.6 \\
5.1\end{array}$ \\
\hline & \multicolumn{6}{|c|}{  } \\
\hline
\end{tabular}

a Bathroom data not included.

TABLE 5. Temperature distribution produced by baseboard convector with room thermostat (inside doors open)

Outside air temperature $4.9^{\circ} \mathrm{F}$, Heat input $27,970 \mathrm{Btu} / \mathrm{hr}$.

\begin{tabular}{|c|c|c|c|c|c|c|}
\hline \multirow{2}{*}{$\begin{array}{l}\text { Height } \\
\text { above } \\
\text { floor }\end{array}$} & \multicolumn{5}{|c|}{ A. Average room temperature } & \multirow{2}{*}{$\begin{array}{c}\text { Maximum } \\
\text { horizontal } \\
\text { temperature } \\
\text { difference } \\
\text { between } \\
\text { rooms }\end{array}$} \\
\hline & $\begin{array}{l}\text { Living } \\
\text { room }\end{array}$ & Kitchen & $\begin{array}{l}\text { North } \\
\text { bed- } \\
\text { room }\end{array}$ & $\begin{array}{l}\text { South } \\
\text { bed- } \\
\text { room }\end{array}$ & Bath & \\
\hline \multirow[t]{3}{*}{$\begin{array}{l}\text { in. } \\
2 \ldots \ldots \\
30 \ldots \ldots \\
60 \ldots \ldots \\
78 \ldots \ldots \\
94 \ldots \ldots\end{array}$} & $\begin{array}{l}{ }^{\circ} F \\
66.6 \\
69.8 \\
70.6 \\
70.9 \\
72.4\end{array}$ & $\begin{array}{l}{ }^{\circ} F \\
65.6 \\
70.1 \\
71.2 \\
72.8 \\
73.6\end{array}$ & $\begin{array}{l}{ }^{\circ} F \\
65.7 \\
68.5 \\
69.6 \\
70.2 \\
70.7\end{array}$ & $\begin{array}{l}{ }^{\circ} \mathrm{F} \\
66.0 \\
69.1 \\
69.8 \\
70.5 \\
71.4\end{array}$ & $\begin{array}{l}{ }^{\circ} \mathrm{F} \\
72.5 \\
78.3 \\
81.6 \\
84.2 \\
86.7\end{array}$ & $\begin{array}{c}\text { Deg F } \\
1.0 \\
1.6 \\
1.6 \\
2.6 \\
2.9\end{array}$ \\
\hline & \multicolumn{5}{|c|}{ B. Vertical temperature difference } & $\begin{array}{l}\text { Average } \\
\text { for } \mathrm{B}^{\mathbf{3}}\end{array}$ \\
\hline & $\begin{array}{r}D e g F \\
4.0 \\
5.8\end{array}$ & $\begin{array}{r}D e g F \\
5.6 \\
8.0\end{array}$ & $\begin{array}{r}D e g F \\
3.9 \\
5.0\end{array}$ & $\begin{array}{r}D e g F \\
3.8 \\
5.4\end{array}$ & $\begin{array}{r}D e g F \\
9.1 \\
14.2\end{array}$ & $\begin{array}{c}D e g F \\
4.3 \\
6.1\end{array}$ \\
\hline & $\begin{array}{l}\text { Average } \\
\text { Average : } \\
\text { Floor sur } \\
\text { Wall surf } \\
\text { Running } \\
\text { Running }\end{array}$ & $\begin{array}{l}\text { asemen } \\
\text { ttie tem } \\
\text { ace tem } \\
\text { lee tem } \\
\text { ime of } \\
\text { ime of }\end{array}$ & $\begin{array}{l}\text { nperat } \\
\text { ature. } \\
\text { ture.. } \\
\text { ture.. } \\
\text { p.... } \\
\text { er.... }\end{array}$ & & $\begin{array}{l}\ldots .45 .9^{\circ} \\
\ldots .35 .7 \\
.63 .3^{\circ} \\
\cdots 60.4 \\
\cdots 100 \% \\
\ldots 55 \%\end{array}$ & \\
\hline
\end{tabular}

athroom data not included.

The room temperatures for most of the tests when the doors were closed decreased in the following order: kitchen, living room, south bedroom, and north bedroom. This was the same order in which the piping circuit progressed through the several rooms from the boiler supply to the boiler return. This room-temperature gradient around the heating circuit showed that the sizes of the last convectors in the circuit were not increased sufficiently to compensate for the lower water temperature. A much smaller gradient in room temperature was observed around the circuit when the interior doors vere 
open than when they were closed, which indicated that some equalization of air temperature occurred when the interior doors were open into the hall. If the convector elements had been accurately selected as to size there should have been practically no temperature difference between rooms.

A comparison of the temperature distribution obtained with the baseboard convector system for two methods of room-temperature control is shown in tables 6 to 9 and tables 10 to 13 . The results in tables 10 to 13 indicate that the vertical temperature differences were a little greater with the out-

TABLE 6. Temperature distribution produced by baseboard convector with room thermostat (inside doors closed)

Outside air temperature $49.9^{\circ} \mathrm{F}$. Heat input $9,220 \mathrm{Btu} / \mathrm{hr}$.

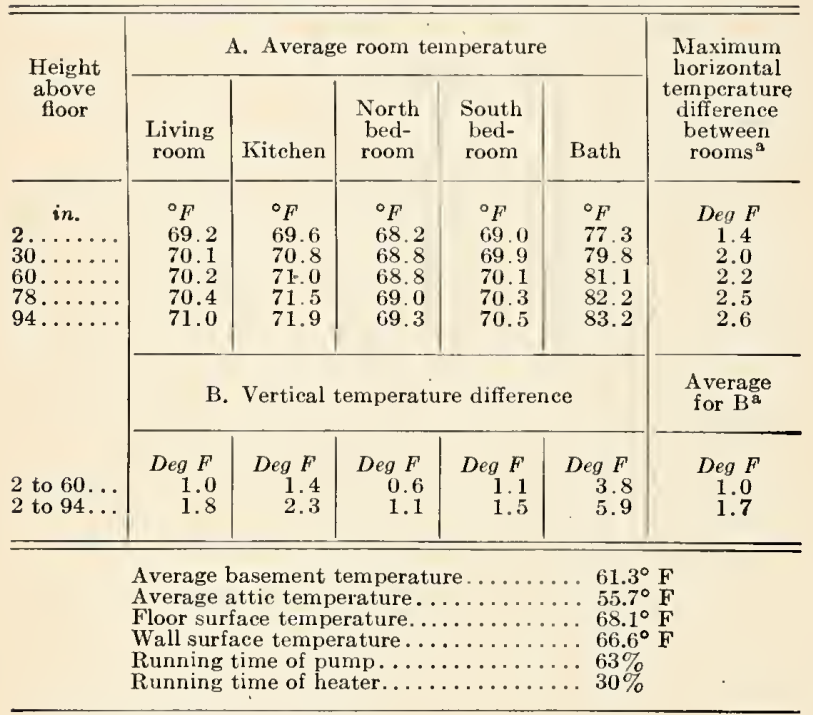

- Bathroom data not included.

TABLE 7. Temperature distribution produced by baseboard convector with room thermostat (inside doors closed)

Outside air temperature $32.1^{\circ} \mathrm{F}$. Heat input $16,530 \mathrm{Btu} / \mathrm{hr}$.

\begin{tabular}{|c|c|c|c|c|c|c|}
\hline \multirow{2}{*}{$\begin{array}{l}\text { Height } \\
\text { above } \\
\text { floor }\end{array}$} & \multicolumn{5}{|c|}{ A. Average room temperature } & \multirow{2}{*}{$\begin{array}{l}\text { Maximum } \\
\text { horizontal } \\
\text { temperature } \\
\text { difference } \\
\text { between } \\
\text { rooms }\end{array}$} \\
\hline & $\begin{array}{l}\text { Living } \\
\text { room }\end{array}$ & Kitchen & $\begin{array}{l}\text { North } \\
\text { bed- } \\
\text { room }\end{array}$ & $\begin{array}{l}\text { South } \\
\text { bed- } \\
\text { room }\end{array}$ & Bath & \\
\hline \multirow[t]{3}{*}{$\begin{array}{l}2 \ldots \\
2 \ldots \ldots \\
30 \ldots \ldots \\
60 \ldots \ldots \\
78 \ldots \ldots \\
94 \ldots \ldots\end{array}$} & $\begin{array}{l}{ }^{\circ} F \\
67.9 \\
69.9 \\
70.3 \\
70.7 \\
71.7\end{array}$ & $\begin{array}{l}{ }^{\circ} \mathrm{F} \\
68.1 \\
70.7 \\
71.1 \\
72.0 \\
72.6\end{array}$ & $\begin{array}{l}{ }^{\circ} \mathrm{F} \\
67.3 \\
69.0 \\
69.2 \\
69.8 \\
70.1\end{array}$ & $\begin{array}{l}{ }^{\circ} \mathrm{F} \\
67.6 \\
69.3 \\
69.8 \\
70.2 \\
70.6\end{array}$ & $\begin{array}{l}{ }^{\circ} \mathrm{F} \\
81.7 \\
87.7 \\
90.0 \\
92.2 \\
93.5\end{array}$ & $\begin{array}{c}\text { Deg } F \\
0.8 \\
1.7 \\
1.9 \\
2.2 \\
2.5\end{array}$ \\
\hline & \multicolumn{5}{|c|}{ B. Vertical temperature difference } & $\begin{array}{l}\text { Average } \\
\text { for } B^{\mathbf{a}}\end{array}$ \\
\hline & $\begin{array}{r}\text { Deg } F \\
2.4 \\
3.8\end{array}$ & $\begin{array}{r}D e g F \\
3.0 \\
4.5\end{array}$ & $\begin{array}{r}\text { Deg } F \\
1.9 \\
2.8\end{array}$ & $\begin{array}{r}\operatorname{Deg} F \\
2.2 \\
3.0\end{array}$ & $\begin{array}{r}D e g F \\
8.3 \\
11.8\end{array}$ & $\begin{array}{c}D e g F \\
2.4 \\
3.5\end{array}$ \\
\hline & $\begin{array}{l}\text { Average } \\
\text { Average } \\
\text { Floor sur } \\
\text { Wall sur } \\
\text { Running } \\
\text { Running }\end{array}$ & $\begin{array}{l}\text { asement } \\
\text { ttic temp } \\
\text { ace temp } \\
\text { lee tempe } \\
\text { ime of pl } \\
\text { ime of he }\end{array}$ & $\begin{array}{l}\text { mperat } \\
\text { rature. } \\
\text { ature.. } \\
\text { ature.. } \\
\text { np.... }\end{array}$ & $\ldots$. & $\begin{array}{ll}\ldots & 54 . \\
\ldots & 46 . \\
\ldots & 66 . \\
\ldots & 64 . \\
\ldots & 81 \\
\ldots & 34\end{array}$ & $\begin{array}{l}F \\
F \\
F \\
F\end{array}$ \\
\hline
\end{tabular}

sathroom data not included. door-thermostat control than with the roomthermostat control except for the lowest outside air temperature. This probably resulted from the higher heat input and higher room temperatures maintained by the outdoor-thermostat control for outside air temperatures of $50^{\circ}, 32^{\circ}$, and $20^{\circ} \mathrm{F}$. The maximum temperature difference between rooms was also slightly greater for the outdoorthermostat control than for the room-thermostat control.

TABLE 8. Temperature distribution produced by baseboard convector with room thermostat (inside doors closed)

Outside air temperature $20.1^{\circ} \mathrm{F}$. Heat input $23,020 \mathrm{Btu} / \mathrm{hr}$.

\begin{tabular}{|c|c|c|c|c|c|c|}
\hline \multirow{2}{*}{$\begin{array}{l}\text { Height } \\
\text { above } \\
\text { floor }\end{array}$} & \multicolumn{5}{|c|}{ A. Average room temperature } & \multirow{2}{*}{$\begin{array}{c}\text { Maximum } \\
\text { horizontal } \\
\text { temperature } \\
\text { difference } \\
\text { between } \\
\text { rooms }^{\mathrm{a}}\end{array}$} \\
\hline & $\begin{array}{l}\text { Living } \\
\text { room }\end{array}$ & Kitchen & $\begin{array}{l}\text { North } \\
\text { bed- } \\
\text { room }\end{array}$ & $\begin{array}{l}\text { South } \\
\text { bed- } \\
\text { room }\end{array}$ & Bath & \\
\hline \multirow[t]{2}{*}{$\begin{array}{l}\text { in. } \\
2 \ldots \ldots \ldots \\
30 \ldots \ldots \\
60 \ldots \ldots \\
78 \ldots \ldots \\
94 \ldots \ldots\end{array}$} & $\begin{array}{l}{ }^{\circ} \mathrm{F} \\
67.4 \\
70.1 \\
70.8 \\
71.1 \\
72.8\end{array}$ & \begin{tabular}{l|l}
${ }^{\circ} \mathrm{F}$ & \\
67.3 & \\
71.0 & \\
71.6 & \\
72.8 & \\
73.5
\end{tabular} & $\begin{array}{l}{ }^{\circ} \mathrm{F} \\
66.5 \\
68.9 \\
69.6 \\
70.2 \\
70.7\end{array}$ & \begin{tabular}{l|l}
$\circ \mathrm{F}$ \\
66.4 \\
68.5 \\
69.0 \\
69.6 \\
70.1
\end{tabular} & \begin{tabular}{l|l}
$\circ F$ \\
84.2 \\
91.4 \\
94.4 \\
97.3 \\
98.3
\end{tabular} & $\begin{array}{l}D e g F \\
1.0 \\
2.5 \\
2.6 \\
3.2 \\
3.4\end{array}$ \\
\hline & \multicolumn{5}{|c|}{ B. Vertical temperature difference } & $\begin{array}{l}\text { Average } \\
\text { for } B^{a}\end{array}$ \\
\hline \multirow[t]{2}{*}{$\begin{array}{l}2 \text { to } 60 \ldots \\
2 \text { to } 94 \ldots\end{array}$} & $\begin{array}{r}\text { Deg } F \\
3.4 \\
5.4\end{array}$ & $\begin{array}{r}\operatorname{Deg} F \\
4.3 \\
6.2\end{array}$ & $\begin{array}{r}D e g F \\
3.1 \\
4.2\end{array}$ & $\begin{array}{r}\operatorname{Deg} F \\
2.6 \\
3.7\end{array}$ & $\begin{array}{r}\text { Deg F } \\
10.2 \\
14.1\end{array}$ & $\begin{array}{c}D e g F \\
3.4 \\
4.9\end{array}$ \\
\hline & \multicolumn{6}{|c|}{ 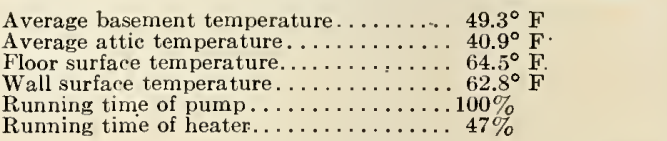 } \\
\hline
\end{tabular}

a Bathroom data not included.

TABLE 9. Temperature distribution produced by baseboard convector with room thermostat (inside doors closed)

Outside air temperature $0.8^{\circ} \mathrm{F}$. Heat input $32,260 \mathrm{Btu} / \mathrm{hr}$.

\begin{tabular}{|c|c|c|c|c|c|c|}
\hline \multirow{2}{*}{$\begin{array}{l}\text { Height } \\
\text { above } \\
\text { floor }\end{array}$} & \multicolumn{5}{|c|}{ A. Average room temperature } & \multirow{2}{*}{$\begin{array}{c}\text { Maximum } \\
\text { horizontal } \\
\text { temperature } \\
\text { difference } \\
\text { between } \\
\text { rooms }^{\mathrm{a}}\end{array}$} \\
\hline & $\begin{array}{l}\text { Living } \\
\text { room }\end{array}$ & Kitchen & $\begin{array}{l}\text { North } \\
\text { bed- } \\
\text { room }\end{array}$ & $\begin{array}{l}\text { South } \\
\text { bed- } \\
\text { room }\end{array}$ & Bath & \\
\hline \multirow[t]{3}{*}{$\begin{array}{c}\text { in. } \\
2 \ldots \ldots \ldots \\
30 \ldots \ldots \ldots \\
60 \ldots \ldots \ldots \\
78 \ldots \ldots \ldots \\
94 \ldots \ldots \ldots\end{array}$} & $\begin{array}{l}{ }^{\circ} \mathrm{F} \\
65.8 \\
69.4 \\
70.0 \\
70.9 \\
72.5\end{array}$ & $\begin{array}{l}\circ F \\
65.4 \\
70.4 \\
71.2 \\
72.9 \\
73.2\end{array}$ & $\begin{array}{l}{ }^{\circ} \mathrm{F} \\
64.0 \\
66.8 \\
67.8 \\
68.6 \\
69.5\end{array}$ & $\begin{array}{l}{ }^{\circ} \mathrm{F} \\
64.0 \\
66.9 \\
67.2 \\
68.6 \\
68.9\end{array}$ & \begin{tabular}{r}
\multicolumn{1}{c}{${ }^{\circ} \mathrm{F}$} \\
85.4 \\
95.1 \\
99.3 \\
102.7 \\
104.9
\end{tabular} & $\begin{array}{c}D e g . F \\
1.8 \\
3.6 \\
4.0 \\
4.3 \\
4.3\end{array}$ \\
\hline & \multicolumn{5}{|c|}{ B. Vertical temperature difference } & $\begin{array}{l}\text { Average } \\
\text { for } \mathrm{B}^{2}\end{array}$ \\
\hline & $\begin{array}{r}D e g F \\
\quad 4.2 \\
\quad 6.7\end{array}$ & $\begin{array}{r}D e g F \\
5.8 \\
7.8\end{array}$ & $\begin{array}{r}\text { Deg } F \\
3.8 \\
5.5\end{array}$ & $\begin{array}{r}D e g F \\
3.2 \\
4.9\end{array}$ & $\begin{array}{r}D e g F \\
13.9 \\
19.5\end{array}$ & $\begin{array}{c}D e g F \\
-4.3 \\
6.2\end{array}$ \\
\hline & $\begin{array}{l}\text { Average } \\
\text { Average } \\
\text { Floor sur } \\
\text { Wall surf } \\
\text { Running } \\
\text { Running }\end{array}$ & $\begin{array}{l}\text { oasement } \\
\text { attic temp } \\
\text { face temp } \\
\text { ace tempe } \\
\text { time of } p \text { i } \\
\text { time of } h\end{array}$ & $\begin{array}{l}\text { mperat } \\
\text { ature. } \\
\text { ature.. } \\
\text { ature... } \\
\text { np.... } \\
\text { ter.... }\end{array}$ & & $\begin{array}{l}\ldots 42.9^{\circ} \\
\ldots .329^{\circ} \\
\cdots \quad 62.2^{\circ} \\
\cdots \quad 60.3^{\circ} \\
\ldots 100 \% \\
\cdots \quad 66 \%\end{array}$ & $\mathrm{~F}$ \\
\hline
\end{tabular}

- Bathroom data not included.

Building Materials and Structures Report BMS115 
TABLE 10. Temperature distribution produced by baseboard convector with outdoor-thermostat control and modulating valve (inside doors closed)

Outside air temperature $50.1^{\circ} \mathrm{F}$, Heat input $12,600 \mathrm{Btu} / \mathrm{hr}$.

\begin{tabular}{|c|c|c|c|c|c|c|}
\hline \multirow{2}{*}{$\begin{array}{l}\text { Height } \\
\text { above } \\
\text { floor }\end{array}$} & \multicolumn{5}{|c|}{ A. Average room tempcrature } & \multirow{2}{*}{$\begin{array}{c}\text { Maximum } \\
\text { horizontal } \\
\text { temperature } \\
\text { difference } \\
\text { between } \\
\text { rooms }{ }^{\mathrm{a}}\end{array}$} \\
\hline & $\begin{array}{l}\text { Living } \\
\text { room }\end{array}$ & Kitchen & $\begin{array}{l}\text { North } \\
\text { bed- } \\
\text { room }\end{array}$ & $\begin{array}{l}\text { South } \\
\text { bed- } \\
\text { room }\end{array}$ & Bath & \\
\hline \multirow[t]{3}{*}{$\begin{array}{c}\quad \text { in. } \\
2 \ldots \ldots \ldots \\
30 \ldots \ldots \ldots \\
60 \ldots \ldots \\
78 \ldots \ldots \ldots \\
94 \ldots \ldots\end{array}$} & $\begin{array}{l}\circ F \\
\text { } 71.1 \\
73.1 \\
73.4 \\
73.6 \\
74.2\end{array}$ & $\begin{array}{l}{ }^{\circ} \mathrm{F} \\
71.4 \\
73.8 \\
74.2 \\
74.6 \\
75.0\end{array}$ & $\begin{array}{l}{ }^{\circ} \mathrm{F} \\
71.1 \\
72.9 \\
72.9 \\
73.2 \\
73.4\end{array}$ & $\begin{array}{l}{ }^{\circ} F \\
71.0 \\
72.2 \\
72.4 \\
72.6 \\
73.0\end{array}$ & $\begin{array}{l}\circ \mathrm{F} \\
84.5 \\
90.1 \\
93.3 \\
96.6 \\
97.9\end{array}$ & $\begin{array}{c}D e g F \\
0.4 \\
1.6 \\
1.8 \\
2.0 \\
2.0\end{array}$ \\
\hline & \multicolumn{5}{|c|}{ B. Vertieal temperature differenee } & $\begin{array}{l}\text { Average } \\
\text { for } \mathrm{B}^{\mathrm{a}}\end{array}$ \\
\hline & $\begin{array}{r}D e g F \\
2.3 \\
3.1\end{array}$ & $\begin{array}{r}D e g F \\
2.8 \\
3.6\end{array}$ & $\begin{array}{r}D e g F \\
1.8 \\
2.3\end{array}$ & $\begin{array}{r}D e g F \\
1.4 \\
2.0\end{array}$ & $\begin{array}{r}\operatorname{Deg} F \\
8.8 \\
13.4\end{array}$ & $\begin{array}{c}D e g F \\
2.1 \\
2.8\end{array}$ \\
\hline
\end{tabular}

Average bascment temperature........ $52.2^{\circ} \mathrm{F}$

Average attic temperature $\ldots \ldots \ldots \ldots \ldots \ldots, 69.3^{\circ} \mathrm{F}$

Floor surface temperature $\ldots \ldots \ldots \ldots \ldots \ldots, 69.4^{\circ} \mathrm{F}$

Average water temperature.................

Temperature drop in system ............... $2.2 \mathrm{deg} F$

Bathroom data not included.

The temperatures observed in the bathroom were not taken into consideration in evaluating the maximum temperature difference between rooms or the average vertical temperature difference for the house, inasmuch as the temperatures were not controllable in this space since it was being used as a utility room for the boiler and circulating pump.

The horizontal temperature differences within each room were small with the baseboard-convector

TABLE 11. Temperature distribution produced by baseboard convector with outdoor-thermostat control and modulating valve (inside doors closed)

Outside air temperature $32.0^{\circ} \mathrm{F}$. Heat input $19,520 \mathrm{Btu} / \mathrm{hr}$.

\begin{tabular}{|c|c|c|c|c|c|c|}
\hline \multirow{2}{*}{$\begin{array}{l}\text { Height } \\
\text { above } \\
\text { floor }\end{array}$} & \multicolumn{5}{|c|}{ A. Average room temperature } & \multirow{2}{*}{$\begin{array}{l}\text { Maximum } \\
\text { horizontal } \\
\text { temperature } \\
\text { difference } \\
\text { between } \\
\text { rooms }\end{array}$} \\
\hline & $\begin{array}{l}\text { Living } \\
\text { room }\end{array}$ & Kitchen & $\begin{array}{l}\text { North } \\
\text { bed- } \\
\text { room }\end{array}$ & $\begin{array}{l}\text { South } \\
\text { bed- } \\
\text { room }\end{array}$ & Bath & \\
\hline \multirow[t]{2}{*}{$\begin{array}{c}\text { in. } \\
2 \ldots \ldots \\
30 \ldots \ldots \\
60 \ldots \ldots \\
78 \ldots \ldots \\
94 \ldots \ldots\end{array}$} & $\begin{array}{l}{ }^{\circ} \mathrm{F} \\
70.8 \\
73.5 \\
73.9 \\
74.3 \\
75.4\end{array}$ & $\begin{array}{l}{ }^{\circ} F \\
70.6 \\
73.7 \\
74.3 \\
75.2 \\
75.6\end{array}$ & $\begin{array}{l}{ }^{\circ} F \\
69.9 \\
71.7 \\
72.2 \\
72.7 \\
73.2\end{array}$ & $\begin{array}{l}{ }^{\circ} F \\
69.3 \\
70.7 \\
71.1 \\
71.2 \\
71.8\end{array}$ & $\begin{array}{r}{ }^{\circ} \mathrm{F} \\
86.2 \\
93.3 \\
96.8 \\
99.3 \\
100.3\end{array}$ & $\begin{array}{c}\operatorname{Deg} F \\
1.5 \\
3.0 \\
3.2 \\
4.0 \\
3.8\end{array}$ \\
\hline & \multicolumn{5}{|c|}{ B. Vertical temperature difference } & $\begin{array}{l}\text { Average } \\
\text { for } B^{a}\end{array}$ \\
\hline $\begin{array}{l}2 \text { to } 60 \ldots \\
2 \text { to } 94 \ldots\end{array}$ & $\begin{array}{r}D e g F \\
3.1 \\
4.6\end{array}$ & $\begin{array}{r}\operatorname{Deg} F \\
3.7 \\
5.0\end{array}$ & $\begin{array}{r}D e g F \\
2.3 \\
3.3\end{array}$ & $\begin{array}{r}\operatorname{Deg} F \\
1.8 \\
2.5\end{array}$ & $\begin{array}{r}\operatorname{Deg} F \\
10.6 \\
14.1\end{array}$ & $\begin{array}{c}\text { Deg F } \\
2.7 \\
3.9\end{array}$ \\
\hline
\end{tabular}

Average basement tempcrature....... $48.9^{\circ} \mathrm{F}$

Average attic temperature............ $47.9^{\circ} \mathrm{F}$

Floor surface temperature..........6. $67.7^{\circ} \mathrm{F}$

Wall surface temperature...............6. $66.6^{\circ} \mathrm{F}$

Average water temperature $\ldots \ldots \ldots \ldots \ldots \ldots$
Temperature drop in system $\ldots \ldots \ldots \ldots$
.

a Bathroom data not ineluded.
TABLE 12. Temperature distribution produced by baseboard convector with outdoor-thermostat control and modulating valve (inside doors closed)

Outside air temperature $20.5^{\circ} \mathrm{F}$. Heat input $24,750 \mathrm{Btu} / \mathrm{hr}$.

\begin{tabular}{|c|c|c|c|c|c|c|}
\hline \multirow{2}{*}{$\begin{array}{l}\text { Height } \\
\text { above } \\
\text { floor }\end{array}$} & \multicolumn{5}{|c|}{ A. Average room temperature } & \multirow{2}{*}{$\begin{array}{c}\text { Maximum } \\
\text { horizontal } \\
\text { temperaturs } \\
\text { difference } \\
\text { between } \\
\text { rooms }\end{array}$} \\
\hline & $\begin{array}{l}\text { Living } \\
\text { room }\end{array}$ & Kitchen & $\begin{array}{l}\text { North } \\
\text { bed- } \\
\text { room }\end{array}$ & $\begin{array}{l}\text { Soutlı } \\
\text { bed- } \\
\text { room }\end{array}$ & Bath & \\
\hline \multirow[t]{3}{*}{$\begin{array}{c}\text { in. } \\
2 \ldots \ldots \ldots \\
30 \ldots \ldots \\
60 \ldots \ldots \\
78 \ldots \ldots \\
94 \ldots \ldots\end{array}$} & $\begin{array}{l}{ }^{\circ} F \\
69.3 \\
72.6 \\
73.3 \\
73.8 \\
75.2\end{array}$ & $\begin{array}{l}{ }^{\circ} F \\
69.5 \\
72.5 \\
74.1 \\
75.5 \\
75.8\end{array}$ & $\begin{array}{l}{ }^{\circ} F \\
67.0 \\
69.1 \\
69.5 \\
70.0 \\
70.6\end{array}$ & $\begin{array}{l}{ }^{\circ} F \\
68.0 \\
70.5 \\
71.2 \\
71.9 \\
72.5\end{array}$ & \begin{tabular}{r}
\multicolumn{1}{c}{${ }^{\circ} F$} \\
86.6 \\
94.8 \\
98.5 \\
100.9 \\
102.6
\end{tabular} & $\begin{array}{c}\text { Deg F } \\
2.5 \\
3.5 \\
4.6 \\
5.5 \\
5.2\end{array}$ \\
\hline & \multicolumn{5}{|c|}{ B. Vertical temperaturc differenee } & $\begin{array}{l}\text { Average } \\
\text { for } B^{a}\end{array}$ \\
\hline & $\begin{array}{r}D e g F \\
4.0 \\
5.9\end{array}$ & $\begin{array}{r}D e g F \\
4.6 \\
6.3\end{array}$ & $\begin{array}{r}\operatorname{Deg} F \\
2.5 \\
3.6\end{array}$ & $\begin{array}{r}D e g F \\
3.2 \\
4.5\end{array}$ & $\begin{array}{r}D e g F \\
11.9 \\
16.0\end{array}$ & $\begin{array}{c}D e g F \\
3.6 \\
5.1\end{array}$ \\
\hline & $\begin{array}{l}\text { Average } \\
\text { Average } \\
\text { Floor sur } \\
\text { Wall surf } \\
\text { Average } \\
\text { Tempera }\end{array}$ & $\begin{array}{l}\text { asement } t \\
\text { tic tempe } \\
\text { ace tempe } \\
\text { lce temper } \\
\text { vater tem } \\
\text { ure drop } \mathrm{i}\end{array}$ & $\begin{array}{l}\text { empera } \\
\text { rature. } \\
\text { ature. } \\
\text { ature. } \\
\text { atuature } \\
\text { er syster }\end{array}$ & & 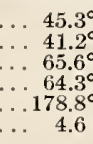 & $\begin{array}{l}F \\
F \\
F \\
F \\
\text { eg } F\end{array}$ \\
\hline
\end{tabular}

- Bathroom data not included.

method of heating. The maximum difference between any two of the five stations in each room ranged from $0.8 \mathrm{deg}$ to $2.1 \mathrm{deg} \mathrm{F}$ for the different tests. The temperature variation within the rooms increased slightly as the outside air temperature was lowered. The average of the maximum within-room variations for the four rooms ranged from $0.9 \mathrm{deg} \mathrm{F}$ for an outsicie air temperature of $50^{\circ} \mathrm{F}$ to $1.7 \mathrm{deg} \mathrm{F}$ for an outside air temperature of $0^{\circ} \mathrm{F}$. No particular

TABLE 13. Temperature distribution produced by baseboard convector with outdoor-thermostat control and modulating valve (inside doors closed)

Outside air temperature $0.9^{\circ} \mathrm{F}$. Heat input $29,480 \mathrm{Btu} / \mathrm{hr}$.

\begin{tabular}{|c|c|c|c|c|c|c|}
\hline \multirow{2}{*}{$\begin{array}{l}\text { Height } \\
\text { above } \\
\text { floor }\end{array}$} & \multicolumn{5}{|c|}{ A. Average room temperature } & \multirow{2}{*}{$\begin{array}{l}\text { Maximum } \\
\text { horizontal } \\
\text { temperature } \\
\text { difference } \\
\text { between } \\
\text { rooms }\end{array}$} \\
\hline & $\begin{array}{l}\text { Living } \\
\text { room }\end{array}$ & Kitehen & $\begin{array}{l}\text { North } \\
\text { bed- } \\
\text { room }\end{array}$ & $\begin{array}{l}\text { South } \\
\text { bed- } \\
\text { room }\end{array}$ & Bath & \\
\hline \multirow[t]{3}{*}{$\begin{array}{c}\text { in. } \\
2 \ldots \ldots \\
30 \ldots \ldots \\
60 \ldots \ldots \\
78 \ldots \ldots \\
94 \ldots \ldots\end{array}$} & $\begin{array}{l}{ }^{\circ} \mathrm{F} \\
66.6 \\
70.2 \\
70.8 \\
71.4 \\
73.0\end{array}$ & $\begin{array}{l}\circ F \\
66.2 \\
70.9 \\
71.9 \\
73.3 \\
74.0\end{array}$ & $\begin{array}{l}{ }^{\circ F} \\
64.6 \\
67.2 \\
68.2 \\
68.6 \\
69.4\end{array}$ & $\begin{array}{l}{ }^{\circ} \mathrm{F} \\
64.0 \\
66.2 \\
66.8 \\
67.5 \\
67.9\end{array}$ & $\begin{array}{r}{ }^{\circ} \mathrm{F} \\
84.4 \\
94.1 \\
97.8 \\
100.2 \\
102.2\end{array}$ & $\begin{array}{c}\text { Deg F } \\
2.6 \\
4.7 \\
5.1 \\
5.8 \\
6.1\end{array}$ \\
\hline & \multicolumn{5}{|c|}{ B. Vertical tcmperature difference } & $\begin{array}{l}\text { Average } \\
\text { for } \mathrm{B}^{\mathrm{a}}\end{array}$ \\
\hline & $\begin{array}{r}\text { Deg } F \\
4.2 \\
6.4\end{array}$ & $\begin{array}{r}D e g F \\
5.7 \\
7.8\end{array}$ & $\begin{array}{r}\text { Deg } F \\
3.6 \\
4.8\end{array}$ & $\begin{array}{r}D e g F \\
2.8 \\
3.9\end{array}$ & $\begin{array}{r}D e g F \\
13.4 \\
17.8\end{array}$ & $\begin{array}{c}D e g F \\
4.1 \\
5.7\end{array}$ \\
\hline , & $\begin{array}{l}\text { Average } \\
\text { Average } \\
\text { Floor sur } \\
\text { Wall sur } \\
\text { Average } \\
\text { Tempera }\end{array}$ & $\begin{array}{l}\text { asement } \\
\text { attie temp } \\
\text { ace temp } \\
\text { acc tempc } \\
\text { vater tem } \\
\text { ure drop }\end{array}$ & $\begin{array}{l}\text { emperat } \\
\text { rature. } \\
\text { rature.. } \\
\text { ature... } \\
\text { n system }\end{array}$ & $\begin{array}{c}\cdots \\
\cdots \cdots \\
\cdots \cdots \\
\cdots \cdots \\
\cdots\end{array}$ & $\begin{array}{lr}\ldots & 42 . \\
\ldots & 33 . \\
\ldots & 62 . \\
\ldots & 59 . \\
\ldots & 191 . \\
\ldots & 5 .\end{array}$ & $\begin{array}{l}F \\
F \\
F \\
F \\
F \\
\operatorname{leg} F\end{array}$ \\
\hline
\end{tabular}

${ }^{\mathbf{a}}$ Bathroom data not included. 
corner of a room was consistently colder at all levels than the other corners and none of the rooms consistently showed greater temperature variation than the others. These observations suggest that the temperature variations that were noted were somewhat random in nature and probably depended in part upon the activities within the rooms during the tests. The smallest horizontal variation in room temperature occurred at the level 30 in. above the floor, but otherwise there was no consistent relation between the uniformity of temperature around the room and the elevation above the floor.

The heat input to the house is recorded in tables 2 to 13 as are also the basement and attic temperatures and the floor- and wall-surface temperatures for the several test conditions. The effect on these temperatures, on the heat loss of the house, and on the vertical temperature differences, of decreasing the outside air temperature is shown by a series of curves in figures 12 and 13 for the tests with roomthermostat control and outdoor-thermostat control, respectively.

These figures also show that the vertical temperature differences between the 2 - and 60 -in. levels and between the 2 - and 94 -in. levels increased as the inside-outside air temperature difference increased,
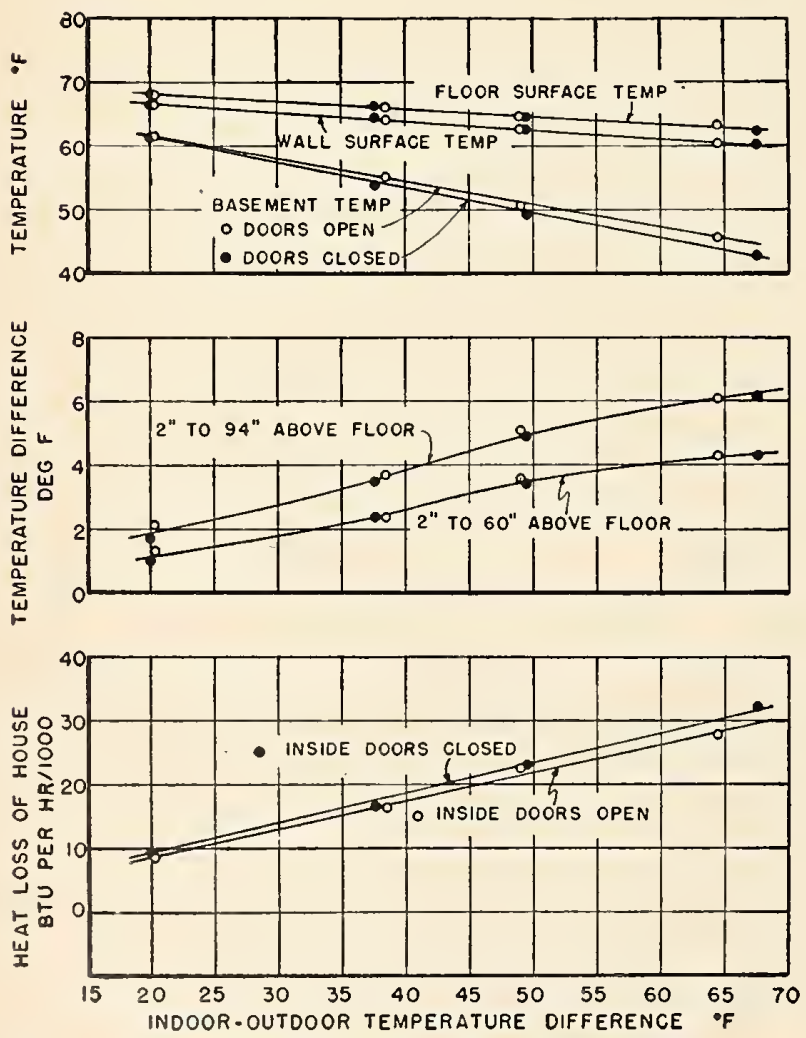

FIGURE 12. Graphs showing the relation of heat loss, vertical temperature differences, basement temperature, wall-surface temperature, and floor-surface temperature to the indooroutdoor temperature difference for the baseboard-convector system with room-thermostat control.
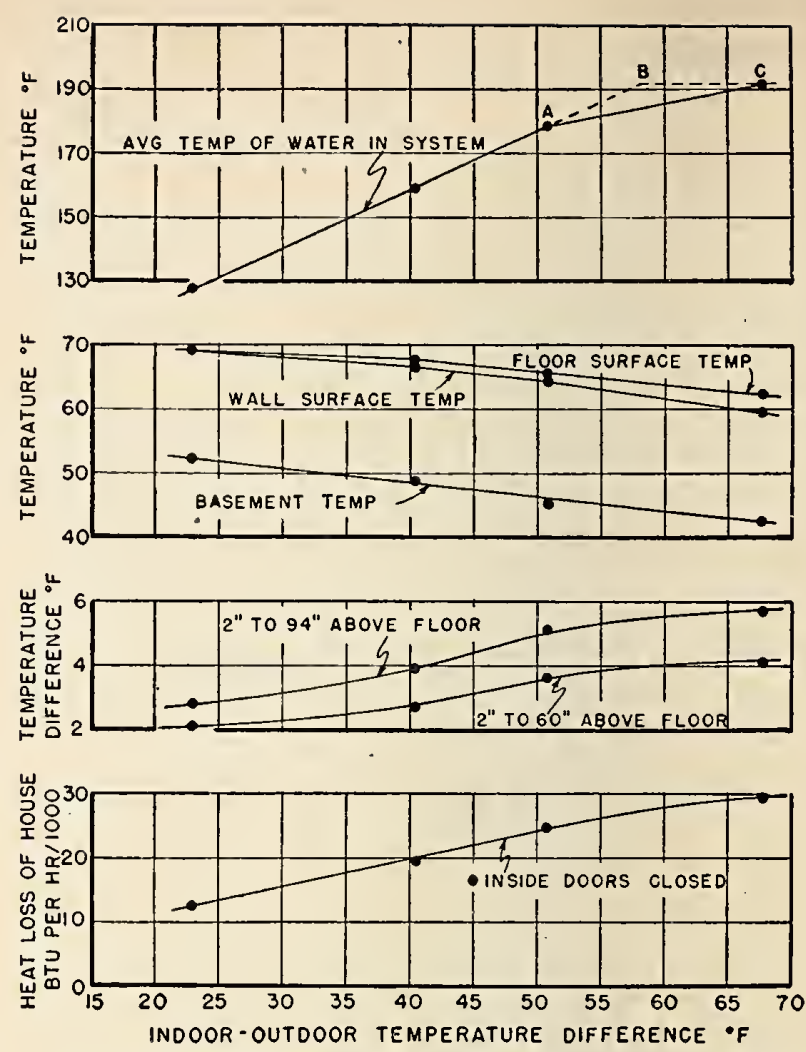

FIGURE 13. Graphs showing the relation of heat loss, vertical temperature differences, basement temperature, wall-surface temperature, floor-surface temperature, and average water temperature in the system to the indoor-outdoor temperature difference for the baseboard-convector system with outdoorthermostat and modulating-valve control system.

but that they were not directly proportional. That is, the curves showing this relationship are not straight lines. The slopes of the curves in both figures 12 and 13 are greater for inside-outside air temperature differences in the range from $35 \mathrm{deg}$ to $50 \mathrm{deg} \mathrm{F}$ than for either higher or lower values of the temperature difference. In figure 12 , the curves approach a zero value of the vertical temperature difference for a zero value of inside-outside air temperature difference whereas in figure 13 the curves indicate that there would still be a vertical temperature gradient with a zero inside-outside air temperature difference. Actually, there probably would be a small vertical temperature difference in the house with an outside air temperature of $70^{\circ} \mathrm{F}$ because of the effect of the earth and basement temperatures on the floor above. The temperature differences between levels were the same whether the inside doors were open or closed, as is shown in figure 12. In figure 12 , the data obtained with the interior doors open were plotted with open circles, whereas those obtained with the interior doors closed were plotted with solid circles.

The curves in figure 12 show that the floor-surface temperature, the average of the wall-surface temperatures 30 - and 60 -in. above the floor, and the 
basement air temperature all decreased uniformly as the inside-outside air temperature difference increased when an electric room thermostat controlled the heating system. No significant differences in floor-surface or wall-surface temperatures were observed with the interior doors open and closed. The basement air temperature was slightly colder for the tests with the interior doors closed, but this result is attributed to greater cooling of the earth around and beneath the house since these tests followed those made with the doors open. It will be noted that the wall-surface temperatures averaged about
2 deg $\mathrm{F}$ lower than the floor-surface temperatures during these tests. In figure 13, the curves show that the floor-surface temperature and wall-surface temperature decreased as the outside air temperature decreased. The slopes of these curves are greater at low outside air temperatures than at high outside air temperatures. This probably occurred because the outdoor thermostat and modulatingcontrol circuit were so adjusted that the average room temperatures at the 30 -in. level decreased from $73.0^{\circ} \mathrm{F}$ for an outside air temperature of $50^{\circ}$ F to $68.6^{\circ} \mathrm{F}$ for an outside air temperature of $1^{\circ} \mathrm{F}$.

\section{Heat Loss}

The heat loss of the Test Bungalow observed at the different outside air temperatures is plotted against inside-outside air-temperature difference in figures 12 and 13 for the two methods of heatingsystem control. In figure 12 , the heat loss of the structure is shown to be directly proportional to the difference in temperature between the inside air and the outside air, although the heat loss averaged about 5 percent more when the interior doors were closed than when they were opened. This increase in heat loss when the doors were closed was due primarily to the overheating of the bathroom (used

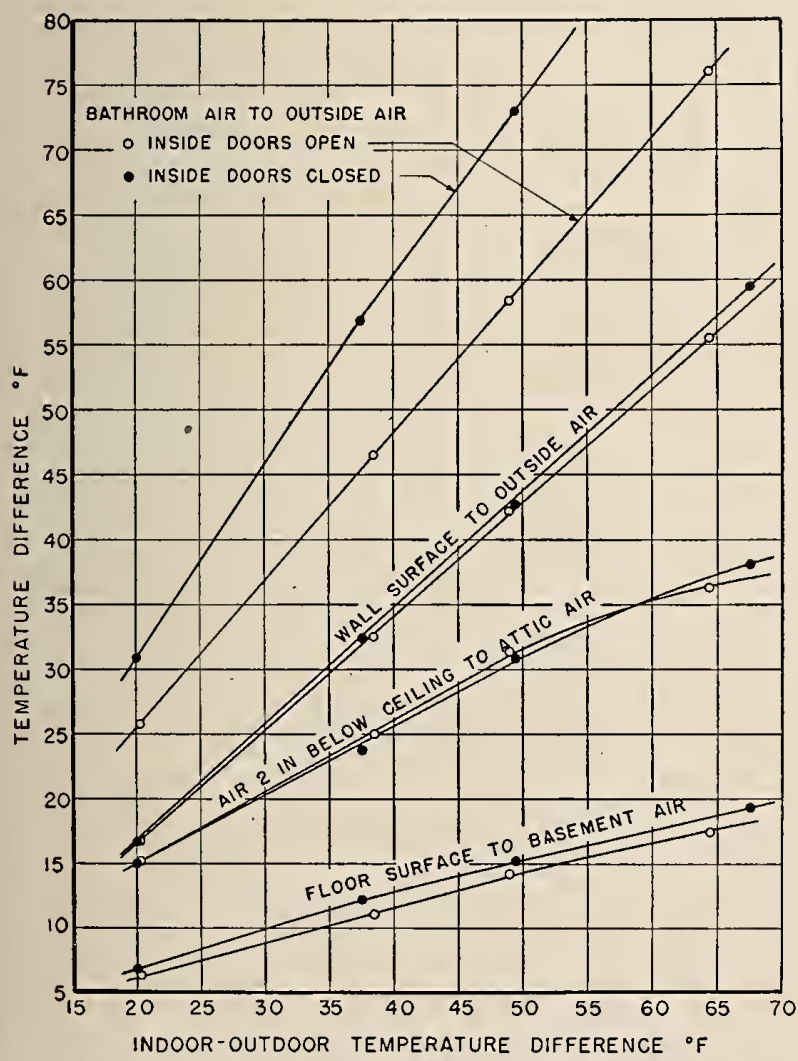

FIGURE 14. Graphs showing the relation of the temperature differences across various building-construction elements of the Test Bungalow to the indoor-outdoor temperature difference for the baseboard-convector system with room-thermostat control. as a utility room) as shown in tables 6 to 9 . For the tests with the outdoor-thermostat control, the heat-loss rate of the house is shown in figure 13 to be a linear function of the inside-outside airtemperature difference for outside air temperatures down to about $15^{\circ} \mathrm{F}$ and then to increase at a lesser rate for outside air temperatures below $15^{\circ} \mathrm{F}$.

The temperature differences across the several construction elements of the house were plotted against inside-outside temperature difference in figures 14 and 15 to determine whether or not they were directly proportional to the inside-outside



FIGURE 15. Graphs showing the relation of the temperature differences across various building construction elements of the Test Bungalow to the indoor-outdoor temperature difference for the baseboard-convector system with the outdoor-thermostat control. 
temperature difference. These curves show that the temperature differences from the wall surface to the outside air and from the bathroom air to the outside air were proportional to the inside-outside temperature difference, but those across the ceiling and floor construction did not remain proportional to the inside-outside temperature difference at the lowest outside air temperatures observed. The heat loss through the floor and ceiling was proportionately less for low outside air temperatures, apparently because steady state conditions were not attained as discussed later. This explains why the heat-loss curve for the entire house shown in figure 13 deviated from a straight line and suggests that a similar, but less pronounced, deviation should have occurred in the heat-loss curve in figure 12.

The departure of the heat-loss curve from a straight line at the lowest outside air temperatures probably resulted at least in part from the fact that the lowest outside air temperatures could only be maintained for 6 to $8 \mathrm{hr}$, with the refrigerating unit, after which the tests were ended. The basement and attic air temperatures were decreasing at the rate of $0.2 \mathrm{deg}$ to $0.5 \mathrm{deg} \mathrm{F} / \mathrm{hr}$ after this length of time and undoubtedly would have leveled off at values lower than those observed. Thus, steady state temperature conditions were not fully attained in either the basement or the attic.

Figure 14 shows that the temperature difference between bathroom air and outside air was considerably greater when the interior doors were closed and that the temperature difference between floor surface and basement air was slightly greater with the interior doors closed than with the doors open. These two deviations probably account for the additional 5-percent heat loss observed for the house as a whole with the interior doors closed.

Figures 12 and 13 show that the heat loss from the Test Bungalow for outside air temperatures above $20^{\circ} \mathrm{F}$ was greater with the outdoor-thermostat contröl than with the room-thermostat control. This was accounted for by the following conditions which existed during the tests: first, higher room temperatures were maintained; second, more, heat was liberated in the bathroom or utility room; and third, the basement air temperature was lower with the outdoor-thermostat control than with the roomthermostat control. The first two conditions were characteristic of the outdoor-thermostat control system while the third condition oceurred because the house had been kept at a low outside air temperature for 2 weeks prior to the tests with the outdoorthermostat control.

\section{Room-Temperature Controls}

The room thermostat used during these tests operated on the principle that a bimetallic element will open and close a low-voltage circuit by deflection caused by changing temperature of the element. Perhaps the only significant difference between the particular type used and other thermostats with bimetallic elements was that the spiral element had a length of approximately $14 \mathrm{in}$., whereas some other room thermostats have elements 2 or 3 inches long. Some air-temperature change is required around the bimetallic element to open and close the contacts since heat must be transferred to and from the element to deflect it. Therefore, the temperature of the air must change more than the change required in the temperature of the element to open and close the contacts. The change in air temperature required to open and close the contacts of the thermostat depends upon (1) the sensitivity of the thermostat mechanism, (2). the heat capacity of the bimetallic element, (3) the degree of shielding and heat capacity of the enclosing case, and (4) the rate of change of the air temperature. If the air-temperature change required to operate the thermostat is too great; the air becomes alternately overheated and overcooled during every thermostat cycle. Usually the overcooling is more readily detected by the occupant than is the overheating. This overcooling of a room, because of the thermostat-response characteristics, has come to be known as the "cold seventies" whereby a person might be too cool for comfort for a time just before the thermostat circuit is closed, even though the thermostat is set at a comfortable temperature.

The change in air temperatures required to operate the room thermostat for three outside air temperatures is shown in table 14 . The air temperatures were observed at the centers of three of the rooms at the 30 -in. level, whereas the thermostat was located at the same level on the living room wall adjacent to the archway between the living room and hall. It will be noted that the change in air temperature due to the thermostat action became less as the outside air temperature decreased. This result was to be expected as the rate of rise of air temperature with time was lower at low outside air temperatures when the heat loss of the house more nearly approached the capacity of the heating system, than at high outside air temperatures, thus

TABLE 14. Room air-temperature differential produced by electric room thermostat

\begin{tabular}{|c|c|c|c|c|c|}
\hline $\begin{array}{l}\text { Outside } \\
\text { air tem- } \\
\text { perature }\end{array}$ & $\begin{array}{l}\text { Temperature } \\
\text { during cycle }\end{array}$ & $\begin{array}{l}\text { Living } \\
\text { room }\end{array}$ & Kitehen & $\begin{array}{l}\text { North } \\
\text { bedroom }\end{array}$ & Average \\
\hline $\begin{array}{r}{ }^{\circ} F^{\prime} \\
32.1 \ldots\end{array}$ & $\left\{\begin{array}{r}\text { Average maximum... } \\
\text { Average minimum ... } \\
\text { Differential..... }\end{array}\right.$ & $\begin{array}{l}{ }^{\circ} F \\
72.2 \\
68.2 \\
4.0\end{array}$ & $\begin{array}{l}{ }^{\circ} F \\
72.7 \\
68.9 \\
3.8\end{array}$ & $\begin{aligned}{ }^{\circ} \mathrm{F} \\
71.2 \\
67.2 \\
4.0\end{aligned}$ & $\begin{array}{c}{ }^{\circ} F \\
\cdots \cdots \\
\cdots \\
3.9\end{array}$ \\
\hline 20.6 . & $\left\{\begin{array}{r}\text { Average maximum... } \\
\text { Average minimum ... } \\
\text { Differential .... }\end{array}\right.$ & $\begin{array}{r}71.7 \\
69.6 \\
2.1\end{array}$ & $\begin{array}{r}71.8 \\
69.8 \\
2.0\end{array}$ & $\begin{array}{r}71.2 \\
69.0 \\
2.2\end{array}$ & $\cdots \cdots$ \\
\hline $0.8 \ldots$ & $\left\{\begin{array}{r}\text { Average maximum ... } \\
\text { Average minimum ... } \\
\text { Differential. . . }\end{array}\right.$ & $\begin{array}{r}70.1 \\
69.0 \\
1.1\end{array}$ & $\begin{array}{r}70.0 \\
69.8 \\
\times \quad 0.2\end{array}$ & $\begin{array}{r}66.9 \\
66.0 \\
0.9\end{array}$ & $\cdots \cdots \ddot{0.7}$ \\
\hline
\end{tabular}


allowing the element more time to follow the air temperature closely. The air-temperature differential ranged from 4.0 deg to 1.1 deg $F$ in the living room for outside air temperatures ranging from $32^{\circ}$ to $1^{\circ} \mathrm{F}$. The temperatures recorded in table 14 were observed with mercury-in-glass thermometers with bulbs approximately $1 / 4$ in. in diameter and $3 / 1$ in. long. The air temperatures at the observation stations undoubtedly changed somewhat more than the thermometers indicated.

The modulating heating-system control operated on the principle that changes in temperature of an outdoor bulb could be relayed to a motor-operated three-way valve at the boiler outlet through a potentiometer circuit in such a way as to change the temperatures of the water entering the heating system just the right amount to maintain a constant room-air temperature at all times. The rate of change of supply-ivater temperature with outside air temperature was adjustable as the range of supply-water temperature required for a given house depends upon the amount of heating surface provided in its heating system. For the baseboard convector system in the Test Bungalow, a range of water temperature from about $80^{\circ}$ to $205^{\circ} \mathrm{F}$ was required for a range of outside air temperature from $65^{\circ}$ to $0^{\circ} \mathrm{F}$. Because this range of water temperature was not obtainable with the control system supplied for the tests, the manufacturer's representative adjusted the controls to supply water to the baseboard convectors at a temperature of about $130^{\circ} \mathrm{F}$ for an outside air temperature of $500^{\circ}$ $\mathrm{F}$ and at a temperature of $195^{\circ} \mathrm{F}$ for an outside air temperature of $0^{\circ} \mathrm{F}$. An approximate adjustment was made by using tabulated information furnished with the control system. The final adjustment was made by repeated trials over a period of several days observation.

'The room temperatures maintained by the modulating control under steady state conditions are summarized in tables 10 to 13 . The average water temperatures in the baseboard-convector circuit are plotted against inside-outside air-temperature differences in figure 13. This relationship was one of direct proportion for outside air temperatures above $20^{\circ} \mathrm{F}$. The actual control of water temperature provided by the modulating valve for insideoutside air-temperature differences above $50^{\circ} \mathrm{F}$ is indicated by the dotted line $\mathrm{A}, \mathrm{B}, \mathrm{C}$ in figure 13 because the control reached the limit of its modulating range at an outside air temperature of $12^{\circ} \mathrm{F}$. For outside air temperatures lower than $12^{\circ} \mathrm{F}$ the supply-ivater temperature remained constant.

Tables 10 to 13 show that the room temperature at the 30 -in. level in the house averaged $73.0^{\circ} \mathrm{F}$ for an outside air temperature of $50.1^{\circ} \mathrm{F}$ and gradually decreased as the outside air temperature decreased until the room temperature averaged

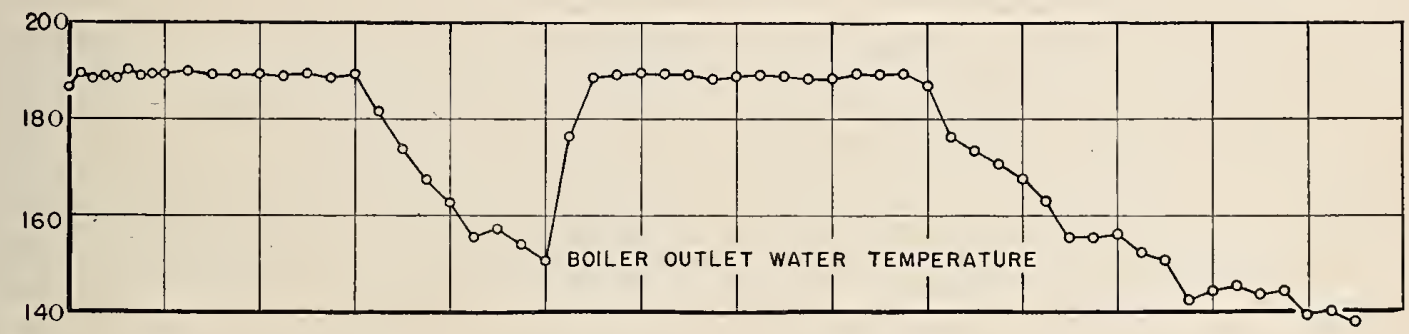

$\div$
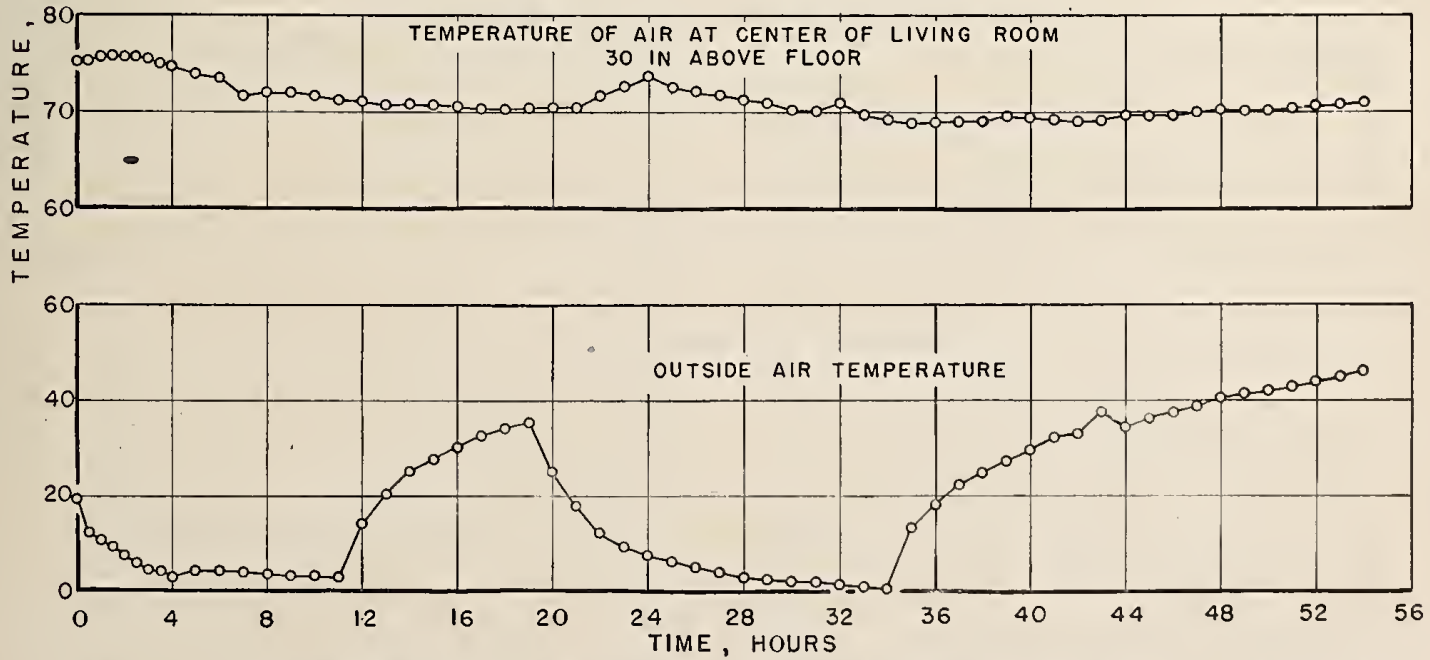

FIGURF-16. Variation of living-room air temperature and boiler-outlet water temperature for transient outside temperatures with the outdoor-thermostat and modulating-valve control system. 
$71.2^{\circ} \mathrm{F}$ for an outside air temperature of $20.5^{\circ} \mathrm{F}$. This gradual decrease of room temperature shows that the rate of change of supply-water temperature with outside air temperature was a little too low to maintain constant room temperatures and that the control mechanism was not quite properly adjusted. It indicates that very careful adjustment by experienced persons would be required to obtain uniform room temperatures with the modulatingcontrol system. In table 13 , the average room temperature at the 30 -in. level is shown to have been $68.6^{\circ} \mathrm{F}$ for an outside air temperature of $0.9^{\circ}$ $\mathrm{F}$. This decrease in room temperature is attributed primarily to the lack of sufficient modulating range by the controller, since it could not raise the supplywater temperature above $195^{\circ} \mathrm{F}$.

During the tests with constant outside air temperatures, when the outdoor thermostat controlled the heating system, there was no cycle in the room temperature similar to that observed with the room thermostat. The maximum change in room temperature occurring during any one test with the outdoor-thermostat control was less than $1 \mathrm{deg} \mathrm{F}$.

The control of room temperature by the outdoor thermostat and modulating valve for rapidly changing outside air temperature is shown in figure 16. The curve for the air temperature at the center of the living room shows that some overheating of the house occurred during periods of rapidly falling outside air temperature and that some underheat- ing occurred during periods of rapidly rising outside air temperature. This result was to be expected because a counter change in the temperature of the supply water occurred immediately in response to a change in outside air temperature whereas the inside air temperatures did not indicate the effect of the outside air-temperature change for an hour or more because of the thermal time lag of the exterior walls. This characteristic of the outdoorthermostat and modulating-control system caused air-temperature changes inside the house as great as $5 \operatorname{deg} \mathrm{F}$ for the pattern of outside air temperatures used during the tests in which the outside air temperature was varied at rates up to $13 \mathrm{deg} \mathrm{F} / \mathrm{hr}$. Outside air temperatures rarely increase or decrease at such a rapid rate as this under natural conditions so that the observed effects are probably of greater magnitude than would occur in actual use of this control.

This characteristic of overanticipating the changes in the heat requirements of a house could be corrected by insulating the outdoor-thermostat bulb sufficiently to provide a thermal time lag in its response equivalent to that of the exterior walls of the house with which it was being used. With such a provision, the heat requirements of the house and the heat supply to the house could be kept more nearly equal during changing outside air temperature conditions than with an uninsulated thermostat bulb.

\section{Pick-Up Characteristics}

The pick-up of the bedroom temperature after night cooling was observed with the outdoor-thermostat control because consideration of the operating principle of this control suggested that it would provide slower pick-up than conventional room-thermostat control. The results of this test are plotted in figure 17. During the test, the bedroom windows were opened and left open for $6 \mathrm{hr}$ until the room temperature had decreased to $50^{\circ} \mathrm{F}$ and leveled off at $52^{\circ} \mathrm{F}$. The interior doors of the house were closed during the $6-\mathrm{hr}$ period and the remainder of the rooms were maintained at approximately $70^{\circ} \mathrm{F}$ by the outdoor-thermostat and modulating control. After cooling the bedrooms for $6 \mathrm{hr}$, the windows were closed simulating the conditions in a house when the occupants arise and wish to warm the bedrooms. The temperatures were observed in each room of the house and at the supply to the baseboard convector system during the pick-up period while the interior doors remained closed.

Seven hours elapsed before the temperature in the north bedroom reached $70^{\circ} \mathrm{F}$ and the temperature in the south bedroom did not approach a steady value of $68^{\circ} \mathrm{F}$ for at least $9 \mathrm{hr}$ after closing the windows. The temperature of the water supplied to the baseboard convector did not change appreciably when the windows were opened or during the pick-up period. A change in supplywater temperature was not to be expected with the outdoor-thermostat control system, however, since the outside air temperature remained constant.

If the interior doors had been opened when the windows were closed, the temperatures of the several rooms would have tended to equalize but the water temperature of the heating system would not have been increased and about the same length of time would have been required to raise the air temperature of the whole house to $70^{\circ} \mathrm{F}$. That is, the outdoor-thermostat control provided no additional heat for raising the temperature in rooms that had been cooled during the night by opening the windows.

With the baseboard convector system, a room thermostat located in the living room would provide the same type of pick-up as that shown in figure 17 if the interior doors were left closed after night cooling of the bedroom. However, if the interior doors were opened, the living-room air would be cooled, whereupon the full capacity of the heating plant would become available for warming the entire house to $70^{\circ} \mathrm{F}$. The time required to accomplish the pick-up would then depend upon the margin of heat emitted by the furnace operating at full capacity above the heat loss occurring at the time. 


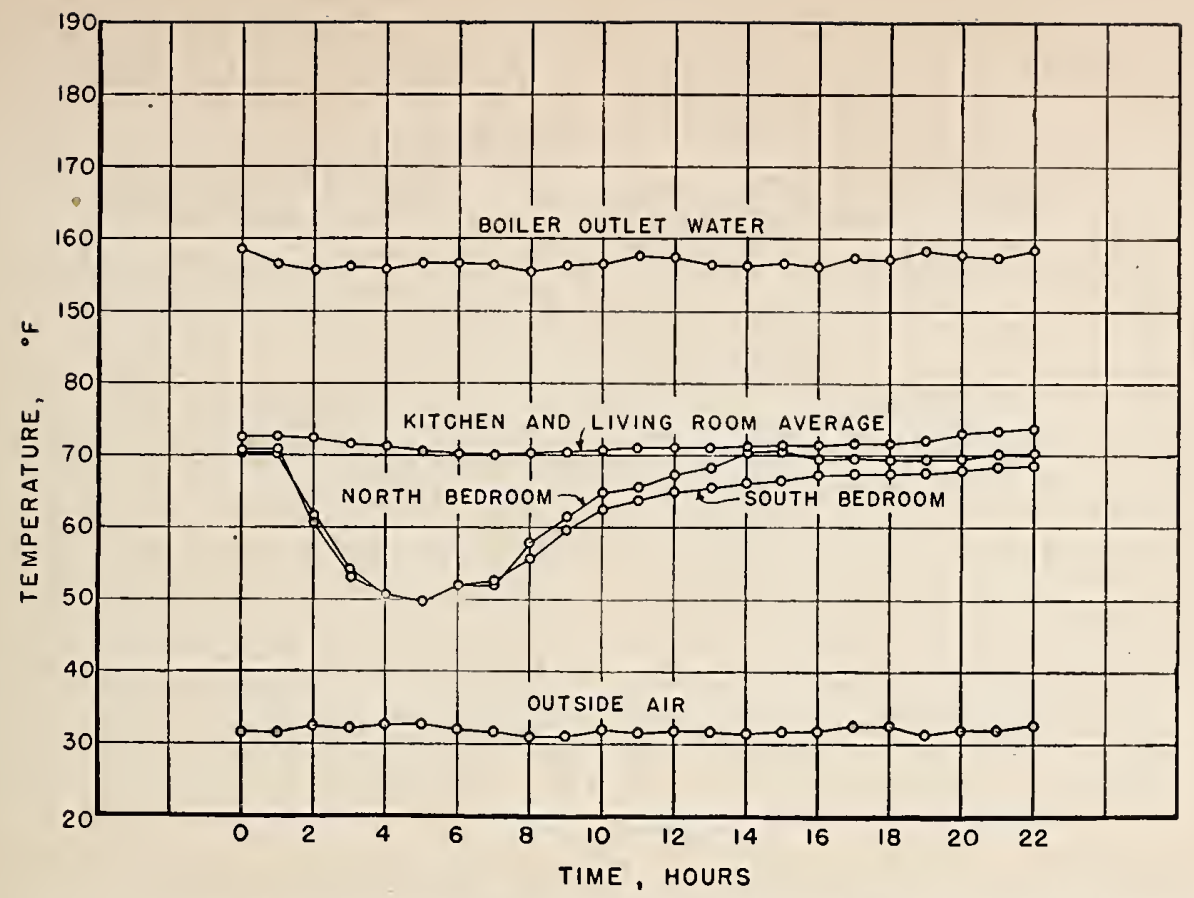

FIGURE 17. Pick-up of bedroom temperature after night cooling with outdoor-thermostat and modulating-valve control system.

\section{Heat Emission of Convector}

The heat output per unit length of the finned convector element was computed for the four tests employing the outdoor-thermostat control for which the average water temperature in the system was observed. The results of these computations are shown in table 15. The gross heat input to the Test Bungalow was diminished by the heat equivalent of the electric energy used by lights, motors, and instruments and by the heat emission of the unfinned 1-in. pipe used to connect the finned elements. There were approximately $85 \mathrm{ft}$ of unfinned pipe in the system including that used adjacent to the pump and boiler. The heat emission of the bare pipe was computed by using the factors tabulated in the GUIDE of the American Society of Heating and Ventilating Engineers for horizontal bare steel pipe. These factors may be slightly different for bare pipe enclosed in a housing such as that used for the baseboard convector. The total heat output of the finned convector elements was divided by the total length of finned pipe installed which was 19.33 ft. Table 15 shows that the heat output per linear foot of convector element ranged from $382 \mathrm{Btu} / \mathrm{hr}$ for a temperature difference of $57 \mathrm{deg} \mathrm{F}$ between water and room air to $957 \mathrm{Btu} / \mathrm{hr}$ for a temperature difference of $126.6 \mathrm{deg} \mathrm{F}$.

TABLE 15. Heat emission of baseboard convector

\begin{tabular}{|c|c|c|c|c|}
\hline Outside air temperature. & 50.1 & 32.0 & 20.5 & 0.9 \\
\hline $\begin{array}{l}\text { Average water tempera- } \\
\text { ture in system......... }\end{array}$ & 128.2 & 159.2 & 178.8 & 191.9 \\
\hline $\begin{array}{l}\text { Temperature difference, } \\
\text { water to inlet air....... Deg } F . .\end{array}$ & 57.0 & 89.0 & 110.3 & 126.6 \\
\hline $\begin{array}{l}\text { Gross heat input to Test } \\
\text { Bungalow.............. } \\
\text { Heat equivalent of }\end{array}$ & 12,600 & 19,520 & 24,750 & 29,480 \\
\hline $\begin{array}{l}\text { Heat equrvatent } \\
\text { lights, motors, etc....... } \\
\text { Gross heat output of }\end{array}$ & 1,820 & 1,820 & 1,830 & 1,830 \\
\hline $\begin{array}{l}\text { boiler ............... Btu/hr.. } \\
\text { Heat output of bare pipe...Btu/hr. }\end{array}$ & $\begin{array}{r}10,780 \\
3,400\end{array}$ & $\begin{array}{r}17,700 \\
5,820\end{array}$ & $\begin{array}{r}22,920 \\
7,650\end{array}$ & $\begin{array}{r}27,650 \\
9,150\end{array}$ \\
\hline $\begin{array}{l}\text { Total heat output of } \\
\text { fnned pipe.......... } \\
\text { Unit heat output of }\end{array}$ & 7,380 & 11,880 & 15,270 & 18,500 \\
\hline finned pipe......... Btu/hr & 382 & 614 & 790 & 957 \\
\hline
\end{tabular}

\section{Discussion and Conclusions}

The comparison of the two methods of heating system control in this report shows that the principal advantages of the outdoor thermostat and modulating-valve control was that it eliminated the fluctuating room temperature caused by the differential of the electric room thermostat. These fluctuations are sometimes excessive and may give rise to the uncomfortable condition known as the cold seventies. The outdoor thermostat and modulating- valve control system would be considerably more expensive initially than the room thermostat and would probably entail the use of more electrical energy for the circulating pump except in the coldest weather since the circulating pump runs constantly with the former control system.

A disadvantage of the particular outdoorthermostat control system used was that it provides no additional heat output for picking up the tem- 
perature of a house in the morning as well as no means for lowering the temperature at night. This feature would be a source of inconvenience to some families who desire to lower the temperature of the house at night and would prevent conservation of fuel by reduction of room temperatures.

The results of this investigation showed that the specimen bascboard convector system produced smaller vertical temperature gradients in the Test Bungalow than any other system or device that had been tested heretofore. For equal outside air temperatures of $20^{\circ} \mathrm{F}$, a temperature differcnce of 3.5 $\operatorname{deg} \mathrm{F}$ rvas observed between the 2 - and 60 -in. levels with the baseboard convector, whereas a temperature difference of $8 \mathrm{deg} \mathrm{F}$ was observed between the same levels for a gravity hot-water heating system with conventional thin tube radiators and a boiler in the basement. However, the Test Bungalow was better insulated for tests with the baseboard convector than for the tests with the hot-water heating system used in this comparison. For this reason the heat loss at an outside air temperature of $0^{\circ} \mathrm{F}$ during the present tests was equivalent to the hcat loss observed at an outside air temperature of $20^{\circ} \mathrm{F}$ when the gravity hot-water heating system was installed in the Test Bungalow. For this condition of equivalent ncat loss, the vertical temperature difference was $8 \mathrm{deg} \mathrm{F}$ for the gravity hot-water heating system and $4.2 \mathrm{deg} \mathrm{F}$ for the baseboard convector system in the living zone for a heat loss of approximately $32,000 \mathrm{Btu} / \mathrm{hr}$.

The low vertical temperaturc differences obtainable with the baseboard convector are attributed to the extended distribution of the elcments around the perimeter of the house and to the strategic location, from a thermal standpoint, of the convectors at the bottom of the cold exterior walls. Analysis of the heat transmission from the interior to the exterior of the Test Bungalow reveals that about 82 percent of the total heat loss of the structure occurred through the exterior walls, the windows and doors, and by infiltration. This 82 percent of the heat loss is largely of a nature that produces downward currents of cold air along the exterior walls. With heating elements distributed around the entire perimeter of the house at the base of the exterior walls, such as the baseboard convectors, these cold currents of air are warmed at the perimeter of the house and are thus prevented from flowing across the floor as they otherwisc. would do.

Measurements in a research house at Purdue University [6] indicate that vertical temperature gradients as low as or lower than those observed with the baseboard convectors can be obtained with a floor-panel heating system. However, such a systcm has not yet been installed in the Test Bungalow for comparison. Lower temperature gradients were observed with radiant baseboard heating in the IBR Research Home [4] than were observed in the Test Bungalow with baseboard convectors. This difference is attributed primarily to the more extensive insulation of the former structure which was built with $35 / 8$-in. rock-wool insulation in all exterior walls and ceiling, with all windows and doors weatherstripped and with storm doors.

Architecturally, the baseboard heating systems present the problem of cutting the baseboard elements to fit the perimeter of the house since the interior dimensions of houses are not standardized. This problem is readily surmounted by the system used in these tests since standard pipe and fittings are uscd to connect the finned elements and the pipe lengths can be cut during installation. The sheet-metal convector housing can also be shortened cluring installation without great difficulty. The installation of a baseboard heating system would be somewhat more difficult in a house with exterior walls of masonry unless they were furred on the inside. In that case the baseboard elements could be supported on the furring strips.

The heat loss of the Test Bungalow could probably have been decreased measurably during the tests by placing loose insulation in the stud spaces back of the baseboard elements to a height of about 1 foot. As shown in figure 7, the pressed-steel rear housing panel for the baseboard convector adjoined the stud space and could, therefore, transmit considerable heat into the stud spaces at the bottom of the walls.

The particular design of convector elements and sheet-metal housing used for these tests was considered somewhat conspicuous and unattractive by most observers. Many people were also of the opinion that the type used in the Test Bungalow projected too far from the wall. However, the relatively high heat output per linear foot of convector obtained with the test specimens suggests that smaller pipe and narrower fins might be employed together with longer elements to improve the appearance without any sacrifice in total capacity. The use of longer finned elements with lower heat emission per linear foot might even decrease the vertical gradient and increase the comfort. The convectors could thus be redesigned to occupy less floor space at the baseboard and have a distinct advantage over free-standing radiators in that respect.

Not every design of baseboard heating element has sufficient heat output per unit of length to heat a house without any insulation even though it is installed around all of the exterior walls. Anyone contemplating the use of baseboard heating should investigate the particular design under consideration to determine whether or not its capacity is adequate for hcating the house to which it is to be applied. The type of element tested would heat any conventional house without insulation since the observed maximum heat emission was approximately $1,000 \mathrm{Btu} / \mathrm{hr}$ per linear foot of finned pipe. A total of 85 linear feet of finned pipe could have been installed in the Test Bungalorv. The resulting heat output of $85,000 \mathrm{Btu} / \mathrm{hr}$ is equivalent to $130 \mathrm{Btu} / \mathrm{hr}$ for each square foot of floor area for the structure, 
which is considerably in excess of the average design heat loss of uninsulated houses in the United States.

The baseboard heating system is well suited for application to basementless houses because it is installed above the floor level except for the special loops below the exterior doors and because it provides better comfort than most other systems at the floor level. However, this type system can also be used in houses with basements with the boiler located below the floor. In spite of the disadvantage of fitting the system to the variable dimensions of conventional houses and its inability to control the heat output to the rooms on an individual basis, the baseboard heating system offers a means for providing more comfortable conditions in dwelling houses than many of the systems now in use.

\section{References}

\section{References Cited in Text}

[1] Richard Eve and J. C. Weston, The economics of house heating, J. Roy. Inst. Brit. Arch. (Nov. 1948).

[2] Richard S. Dill and Paul R. Achenbach, Temperature distribution in a Test Bungalow with various heating devices, NBS Building Materials and Structures Report BMS108 (1947).

[3] A. P. Kratz and M. Fahnestock, Steam condensation an inverse index of heating effect, Trans. Am. Soc. Heating Ventilating Engrs. (1931).

[4] A. P. Kratz and W. S. Harris, A study of radiant baseboard heating in the IBR research home, Univ. Ill. Eng. Expt. Sta. Bul. 358 (Aug. 30, 1945).

[5] Paul R. Achenbach, Temperature distribution in a Test Bungalow with radiant and jacketed space heaters, NBS Building Materials and Structures Report BMS114 (1949).

[6] J. M. Ayres and B. W. Levy, Air temperature gradients in a panel heated room, Heating, Piping and Air Conditioning Mag. (Oct. 1947).

\section{Additional References}

A. P. Kratz and S. Konzo, Investigation of oil-fuel forced-air furnace systems in the research residence. Univ. IL. Eng. Expt. Sta. Bul. 318 (Nov 7,'1939).

\section{Glossary of Selected Heating Terms}

This glossary was compiled to assist the reader with definitions and explanations of a selected number of terms used in this report. Another list of heating, ventilating, and air-conditioning terms will be found in the current issue of the GUIDE published by the American Society of Heating and Ventilating Engineers.

Air change.-An air change is a volume of air equivalent to the interior volume of the occupied portion of a house.

Baseboard convector.-A heating element used in the position normally occupied by the baseboard in a house and designed to transfer heat to a room primarily by convection.

Bimetallic element.-A temperature-sensitive element that is deflected by a temperature change because of the unequal expansion of the two different metals of which it is composed.

Comfort charts. - Charts published by the American Society of Heating and Ventilating Engineers showing the relation between an index of comfort called "effective temperature" based on experiments with human subjects and the dry-bulb temperature, relative humidity, and air motion.

Convection.-The transfer of heat by the movement of a liquid or gas over a heating or cooling surface.

Crawl space.-A shallow space beneath the floor inside the foundation walls of a house.

Dry-bulb temperature.-The temperature of air indicated by an accurate thermometer suitably shielded from radiation.

Electric room thermostat.-A temperature-sensitive device located within a heated space that automatically controls the heat delivery to that space by opening and closing an electrical circuit.
Immersion aquastat.-A thermostat installed in a pipe or tank to control the temperature of the fluid therein by actuating suitable controls.

Infiltration.-The leakage of air into a house through cracks and small openings in floor, ceiling, and exterior walls.

Manometer.-An instrument usually filled with water, mercury, or light oil used for measuring small pressure differences.

Modulating control system.-A control or group of controls that adjusts the heat delivery of a heating system either smoothly or in small steps between the minimum and maximum values as required to offset the heat loss of a house for any outdoor temperature likely to occur.

Outside-thermostat control. - A temperature-sensitive device located outdoors that increases the heat delivery to a house when the outside air temperature decreases.

Pick-up conditions.-Any condition for which the heating plant must raise the temperature in all or a part of the living space.

Radiant baseboard element.-A heating element which emits a considerable portion of its heat to the living space by radiation placed in the position normally occupied by the baseboard.

Radiation.-The transfer of heat by a wave motion similar to that by which light is transmitted.

Relative humidity.-Approximately, the ratio of the weight of moisture in a quantity of air to the weight of moisture in the same quantity of air at the same temperature when saturated.

Steady state. - A temperature distribution that does not change with time.

Temperature-limit control. - A temperature-sensitive element, installed in the hot-water supply line 
of a boiler or the bonnet of a furnace, that shuts off the burner or retards the rate of heat generation when a selected maximum outlet temperature has been reached.

Thermal time lag.-The time required for heat to pass through a material or combination of materials used in walls, floors, or other construction elements.
Three-way mixing valve.-A valve, with two inlets and one outlet, which blends two streams of water at different temperatures in varying proportions by means of a double-faced disk to produce the outlet temperature required by its control mechanism.

Washington, March 4, 1949. 




\title{
BUILDING MATERIALS AND STRUCTURES REPORTS
}

\author{
[Continued from cover page Ir]
}

BMS32 Structural Properties of Two Brick-Concrete-Block Wall Constructions and a ConcreteBlock Wall Construction Sponsored by the National Concrete Masonry Association.... 15\&

BMS33

BMS34

BMS35

BMS36

BMS37

BMS38

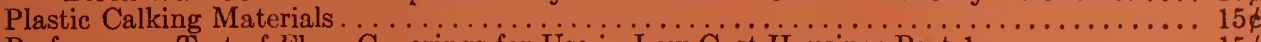

Performance Test of Floor Coverings for Use in Low-Cost Housing: Part $1 \ldots \ldots \ldots \ldots \ldots 15$



"IRed Stripe" Lath Sponsored by The Weston Paper and Manufacturing Co.......... 10

Structural Properties of "Palisade Homes" Constructions for Walls, Partitions, and Floors,

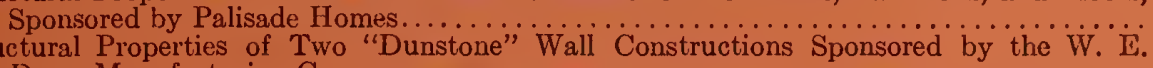

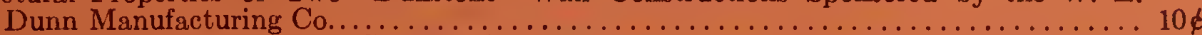

BMS39 Structural Properties of a Wall Construction of "Pfeifer Units" Sponsored by the Wisconsin

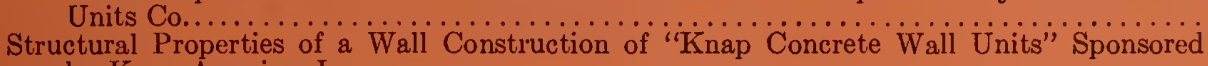

BMS40

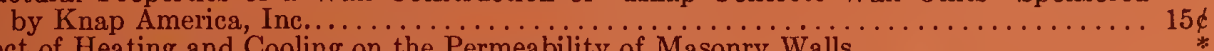

BMS41

BMS42

Structural Properties of Wood-Frame Wall and Partition Constructions with "Celotex" Insulating Boards Sponsored by The Celotex Corporation ............... $15 \varnothing$

BMS43

BMS44

BMS45

BMS46

BMSt7

Performance Test of Floor Coverings for Use in Low-Cost Housing: Part $2 \ldots \ldots \ldots \ldots \ldots \ldots 15$



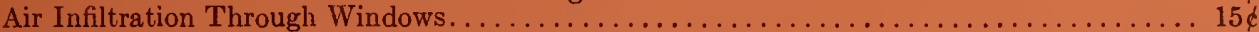

Structural Properties of "Scott-Bilt" Prefabricated Sheet-Steel Constructions for Walls, Floors, and Roofs Sponsored by The Globe-Wernicke Co....................

Structural Properties of Prefabricated Wood-Frame Constructions for Walls, Partitions, and Floors Sponsored by American Houses, Inc..................... 20

BMS48

Structural Properties of "Precision-Built" Frame Wall and Partition Constructions Spon-

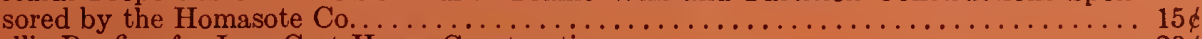

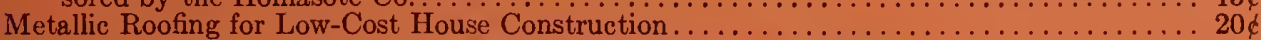

BMS49

Stability of Fiber Building Boards as Determined by Accelerated Aging..................

BMS50

BMS51

Structural Properties of "Tilecrete Type A" Floor Construction Sponsored by the Tilecrete Co.

BMS52

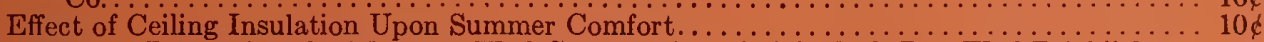

Structural Properties of a Masonry Wall Construction of "Munlock Dry Wall Brick" Sponsored by the Munlock Enginecring Co...

BMS54

BMS55

BMS56

BMS57

BMS58

BMS59

BMS60

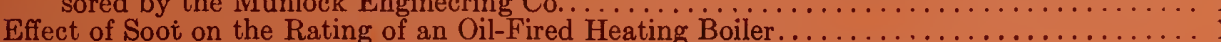

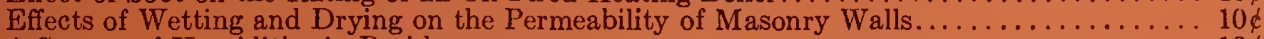

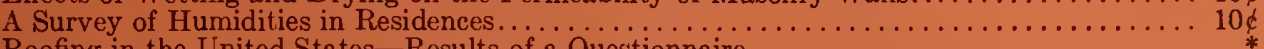

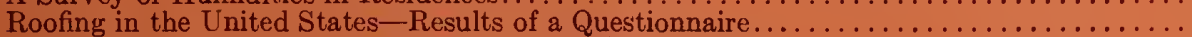

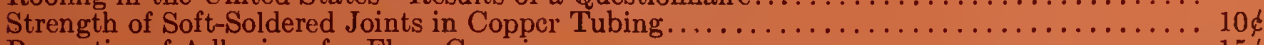

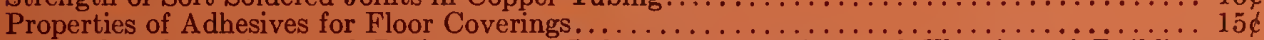

Strength, Absorption, and Resistance to Laboratory Freezing and Thawing of Building

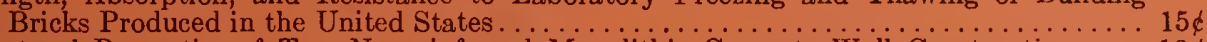

BMS61

BMS62

Structural Properties of Two Nonreinforced Monolithic Concrete Wall Constructions....... $10 \notin$

Structural Properties of a Precast Joist Concrete Floor Construction Sponsored by the Port-

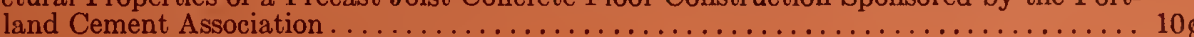

BMS63

BMS64

BMS65

BMS66

BMS67

BMS68

BMS69

BMS70

BMS71

BMS72

BMS73

BMS74

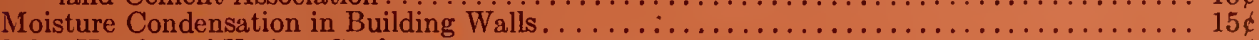

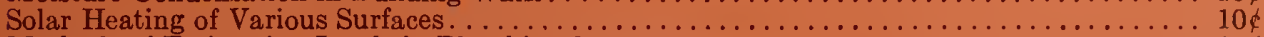

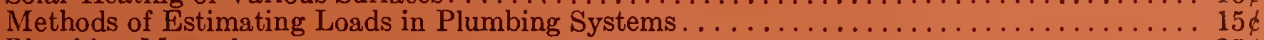

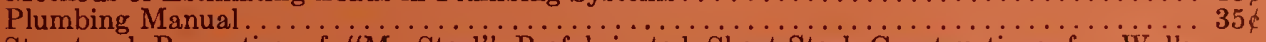

Structural Properties of "Mu-Steel" Prefabricated Sheet-Steel Constructions for Walls,

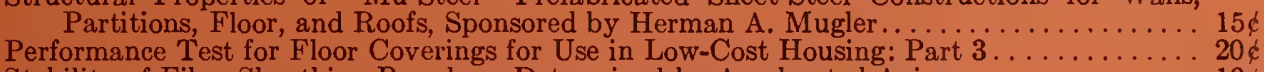

Stability of Fiber Sheathing Boards as Determined by Accelerated Aging............ 10 e

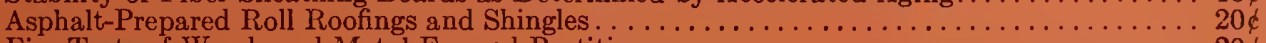

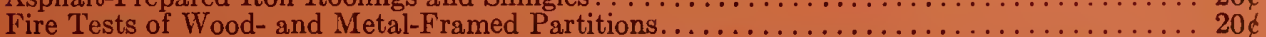

Structural Properties of "Precision-Built, Jr." Prefabricated Wood-Frame Wall Construction Sponsored by the Homasote Co...........................

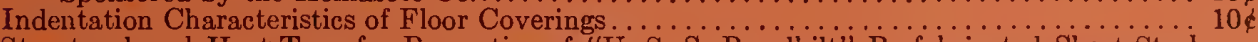

Structural and Heat-Transfer Properties of "U. S. S. Panelbilt" Prefabricated Sheet-Steel Constructions for Walls, Partitions, and Roofs Sponsored by the Tennessee Coal, Iron

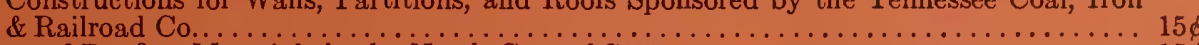

BMS75

BMS76

BMS77

BMS78

BMS79

BMS80

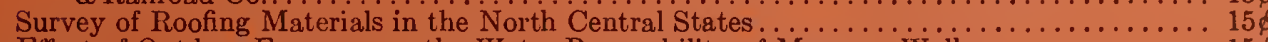

Effect of Outdoor Exposure on the Water Permeability of Masonry Walis....................

Properties and Performance of Fiber Tile Boards................................

Structural, Heat-Transfer, and Water-Perneability Properties of Five Earth-Wail Con-

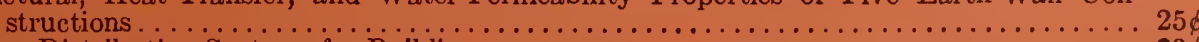

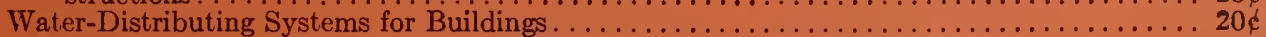

Performance Test of Floor Coverings for Use in Low-Cost Housing: Part $4 \ldots \ldots \ldots \ldots \ldots \ldots$. $\ldots \ldots \ldots$

Field Inspectors' Check List for Building Constructions (cloth cover, 5 x $71 / 2$ inches)........ 20

-Out of print. 


\section{BUILDING MATERIALS AND STRUCTURES REPORTS}

[Continued from cover page $\mathrm{Ir}$ ]

BMS82

BMS83

BMS84

BMS85

BMS86

BMS87

BMS88

BMS89

BMS90

BMS91

BMS92

BMS93

BMS94

BMS95

BMS96

BMS97

BMS98

BMS99

BMS100

BMS101

BMS102

BMS103

BMS104

BMS105

BMS106

BMS107

BMS108

BMS109

BMS110

BMS111

BMS112

BMS113

BMS114

BMS115
Water Permeability of Walls Built of Masonry Units.

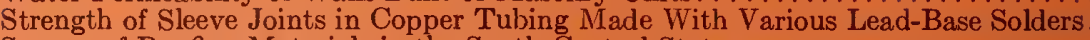

Survey of Roofing Materials in the South Central States.

Dimensional Changes of Floor Coverings With Changes in Relative Humidity and Tempera ture.

Structural, Heat-Transfer, and Water-Permeability Properties of "Speedbrik" Wall Construction Sponsored by the General Shale Products Corporation...................

A Method for Developing Specifications for Building Construction-Report of Subcommittee
on Specifications of the Central Housing Committee on Research, Design, and Con-

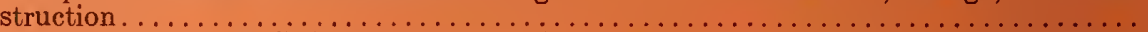

Recommended Building Code Requirements for New Dwelling Construction With Special

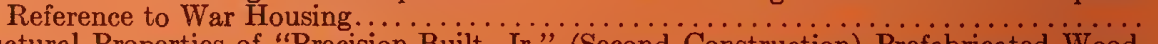
Structural Properties of "Precision-Built, $\mathrm{J}_{r}$, " (Second Construction) Prefabricated WoodFrame Wall Construction Sponsored by the Homasote Co. . . . . . . . . . . . . . . . Structural Properties of "PHC" Prefabricated Wood-Frame Constructions for W Walis, Floors, and Roofs Sponsored by the PHC Housing Corporation. . . . . . . . . . . . . . . A Glossary of Housing Terms.


Accumulation of Moisture in Walls of Frame Construction During Winter Exposure........ Water Permeability and Weathering Resistance of Stucco-Faced, Gunite-Faced, and "Knap

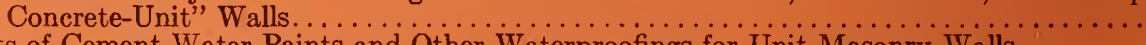

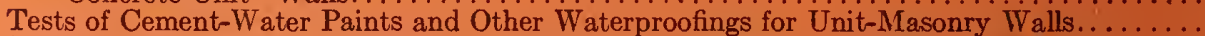
Properties of a Porous Concrete of Cement and Uniform-Sized Gravel . . . . . . . . . . . Expcrimental Dry-Wall Construction With Fiber Insulating Board $\ldots \ldots \ldots \ldots \ldots \ldots \ldots \ldots \ldots$ Physical Properties of Terrazza Aggregates ........................ Structural and Heat-Transfer Properties of "Multiple Box-Girder Plywood Panels" for Walls, Floors, and Roofs.

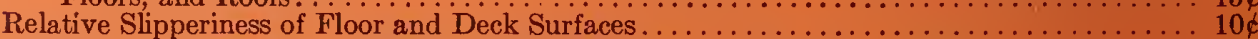
Strength and Resistance to Corrosion of Ties for Cavity Walls $\ldots \ldots \ldots \ldots \ldots \ldots \ldots \ldots \ldots \ldots \ldots$

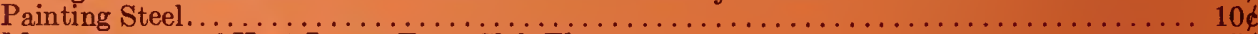

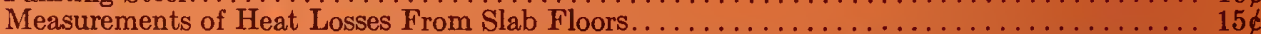
Structural Properties of Prefabricated Plywood Lightweight Constructions for Walls, Partitions, Floors, and Roofs Sponsored by the Douglas Fir Plywood Association......... 30 \&

Paint Manual with particular reference to Federal Specifications . . . . . . . . . . . . $\$ 1.00$

Laboratory Observations of Condensation in Wall Specimens $\ldots \ldots \ldots \ldots \ldots \ldots \ldots \ldots \ldots \ldots \ldots$

Building Code Requirements for New Dwelling Construction

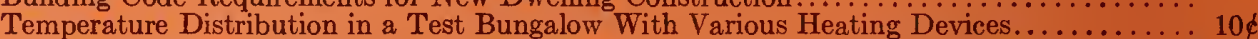
Strength of Houses: Application of Engineering Principles to Structural Design . . . . . . $\$ 1.50$

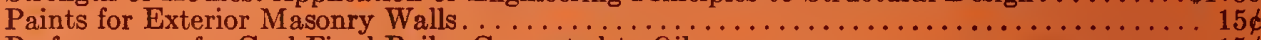

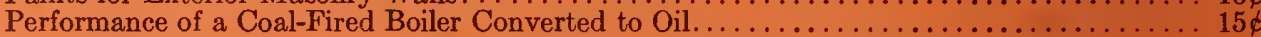
Properties of Some Lightweight-Aggregate Concretes With and Without an Air-entraining

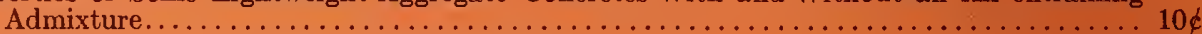

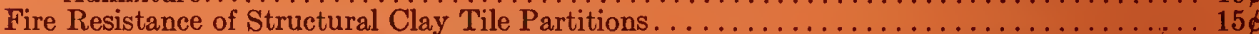
Temperature in a Test Bungalow With Some Radiant and Jacketed Space Heaters....... 25\& A Study of a Baseboard Convector Heating System in a Test Bungalow............. 15 \&

*ut of print. 